\title{
Working
}

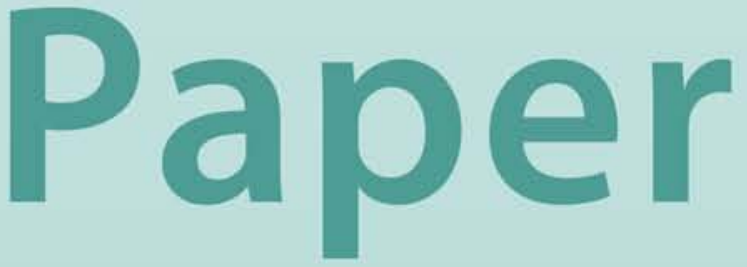


Can Higher Reserves Help Reduce Exchange Rate Volatility?

Ketil Hviding, Michael Nowak, and Luca Antonio Ricci 


\title{
IMF Working Paper
}

African Department, Policy Development and Review Department, and Research Department

\section{Can Higher Reserves Help Reduce Exchange Rate Volatility?}

Prepared by Ketil Hviding, Michael Nowak, and Luca Antonio Ricci ${ }^{1}$

Authorized for distribution by Gian Maria Milesi-Ferretti, Michael Nowak and

Marianne Schulze-Ghattas

October 2004

\begin{abstract}
This Working Paper should not be reported as representing the views of the IMF.

The views expressed in this Working Paper are those of the author(s) and do not necessarily represent those of the IMF or IMF policy. Working Papers describe research in progress by the author(s) and are published to elicit comments and to further debate.

This paper studies the role of an increase in foreign exchange reserves in reducing currency volatility for emerging market countries. The study employs a panel of 28 countries over the period 1986-2002. Several control variables are introduced in the regressions to account for other factors affecting exchange rate volatility (monetary and external indicators as well as conventional macroeconomic fundamentals). The paper controls for the endogeneity induced by the role of the exchange rate regime, since the regime can affect both the level of reserves and exchange rate volatility. The results provide ample support for the proposition that holding adequate reserves reduces exchange rate volatility. The effect is strong and robust; moreover, it is nonlinear and appears to operate through a signaling effect.

JEL Classification Numbers: F30, F31

Keywords: Foreign exchange volatility, reserves, reserve adequacy

Author(s) E-Mail Address: khviding@imf.org, mnowak@imf.org, lricci@imf.org

\footnotetext{
${ }^{1}$ The authors are grateful for comments by Carol Baker, Jorge Ivan Canales Kriljenko, Burkhard Drees, Xavier Hamann, Cem Karacadag, Jun Kim, Timothy D. Lane, Miguel Messmacher, Sunil Sharma, and participants in the seminars at the IMF African and Research Departments, LUISS University, University of Bari, and workshops with the South African National Treasury and the South African Reserve Bank. We are also indebted to Roberto Rigobon, who kindly shared his program to run the identification through heteroscedasticity (IH) estimation. All remaining errors are the responsibility of the authors.
} 


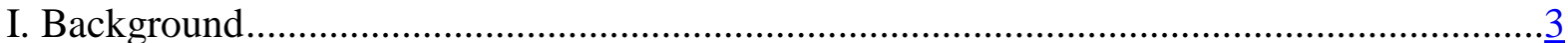

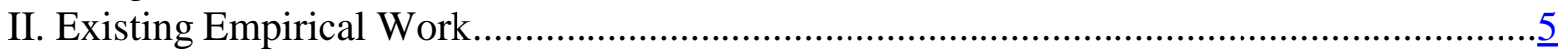

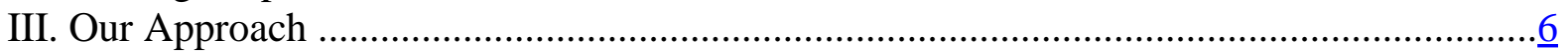

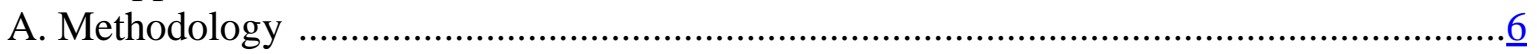

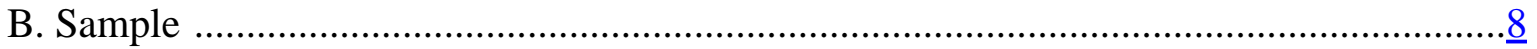

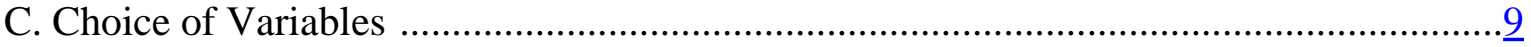

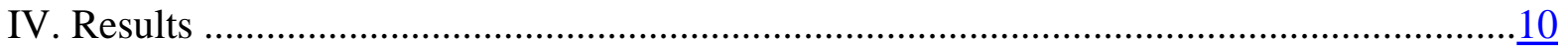

V. Quantifying the Estimated Effects …...............................................................14

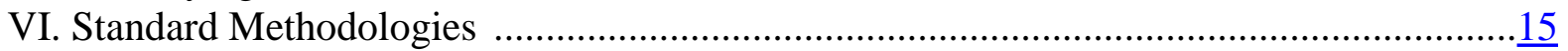

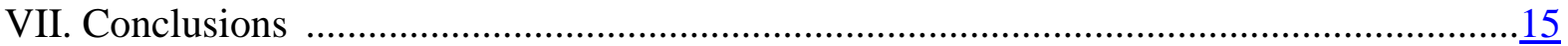

Tables

1. Descriptives: 1994-2002, 28 Emerging Markets..........................................................19

2. Volatility of Growth in REER, Basic Table: 1994-2002 …..........................................20

3. Volatility of Growth in REER, Sample Changes: 1994-2002 ......................................21

4. Volatility of Growth in REER, Other Reserve Measures: 1994-2002 .............................22

5. Volatility of Growth in REER, Basic Table: 1986-2002 ..............................................23

6. Volatility of Growth in REER, Basic Table: 1994-2002 ..............................................24

7. Volatility of Growth in REER, Sample Changes: 1994-2002 ….....................................

8. Volatility of Growth in REER, Other Reserve Measures: 1994-2002 .............................26

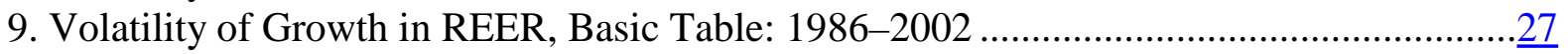

10. Identification Through Heteroscedasticity (IH): 1994-2002 ........................................

11. Volatility of Growth in REER, OLS and Fixed Effects: 1994-2002 .............................29

Figures

1. Reserve Adequacy and Real Exchange Rate Volatility: 1994-2002 ..................................

2: Outliers Versus Leverage Residuals: 1994-2002 .........................................................

3: Outliers Versus Leverage Residuals: 1986-2002 …........................................................

Boxes

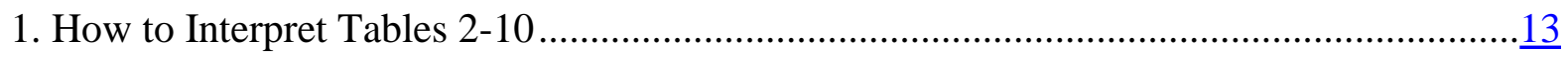

Appendix

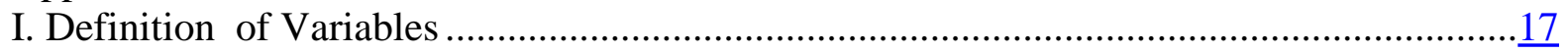

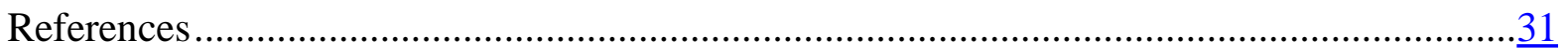




\section{BACKGROUND}

The purpose of this paper is to investigate whether holding higher reserves may reduce the volatility of the real exchange rate independently of the influence of the choice of exchange rate regime or of the role of foreign exchange intervention. The existence of such an effect would be particularly important for countries with more or less freely floating exchange rates, as is the case for an increasing number of emerging market economies: at the end of 2002, as many as 25 out of 31 emerging market economies could be classified as having freely floating or managed floating exchange regimes. ${ }^{2}$ The notion that volatility of the real exchange rate should be a source of concern is not viewed unanimously in the literature. ${ }^{3}$ Nonetheless such concerns are clearly present among policymakers, particularly in emerging market countries, and therefore warrant further attention. ${ }^{4}$

Existing literature has focused mainly on two classes of benefits arising from a high level of reserves. Most prominently, a high level of reserve adequacy has been shown to reduce the likelihood of currency crises or a "sudden stop" - that is, a sudden unwillingness by international lenders to renew their credit lines at times of market uncertainty. ${ }^{5}$ A second beneficial effect is that higher reserve adequacy tends to be associated with lower external borrowing costs. This effect works both directly through improved confidence and indirectly through improved credit ratings on sovereign foreign currency debt, since the government's default risk is perceived to diminish with higher reserves. ${ }^{6}$

We attempt in this paper to identify a third beneficial effect of holding reserves: namely, that holding sufficient reserves can help reduce real exchange rate volatility. Casual observation of a plot of real exchange rate volatility against the ratio of reserves to short-term debt-a measure of reserve adequacy — for a selection of emerging market economies suggests that a negative relationship existed during 1994-2002 (Figure 1, Panel A). ${ }^{7}$ This relationship, moreover, seems to be non-linear, to the extent that the benefits of holding reserves for lowering volatility

${ }^{2}$ For a discussion of why not all countries that claim that they are floating are really floating, see Hausmann, Panizza, and Stein (2001).

${ }^{3}$ See Clark and others (2003).

${ }^{4}$ See for example, a recent statement by the New Zealand Reserve Bank Governor Alan Bollard of March 11, 2004 and a joint press statement of the Governor of the South African Reserve Bank and Minister of Finance Trevor Manual of December, 21, 2001.

${ }^{5}$ See, for example, Calvo and Reinhart (1999); Caramazza, Ricci, and Salgado (2004); and IMF (1998). See Lee (2004) for an option pricing approach to the demand for reserves.

${ }^{6}$ See, for example, Mulder, Perrelli, and Rocha (2002) and Jonsson (2001).

${ }^{7}$ The list of emerging market economies is listed in Section III.B. 
diminish with higher reserve levels. In fact, all incidences of observed annual volatility higher than 5 percent were associated with reserve coverage ratios below 2, and most observations of high volatility were observed in the $0-1$ range. Panel B of Figure 1 shows that this relationship is present even when "outliers” — defined as observations that deviated by more than 2 standard deviations from the mean-are removed.

Figure 1. Reserve Adequacy and Real Exchange Rate Volatility: 1994-2002

Panel A. With all observations

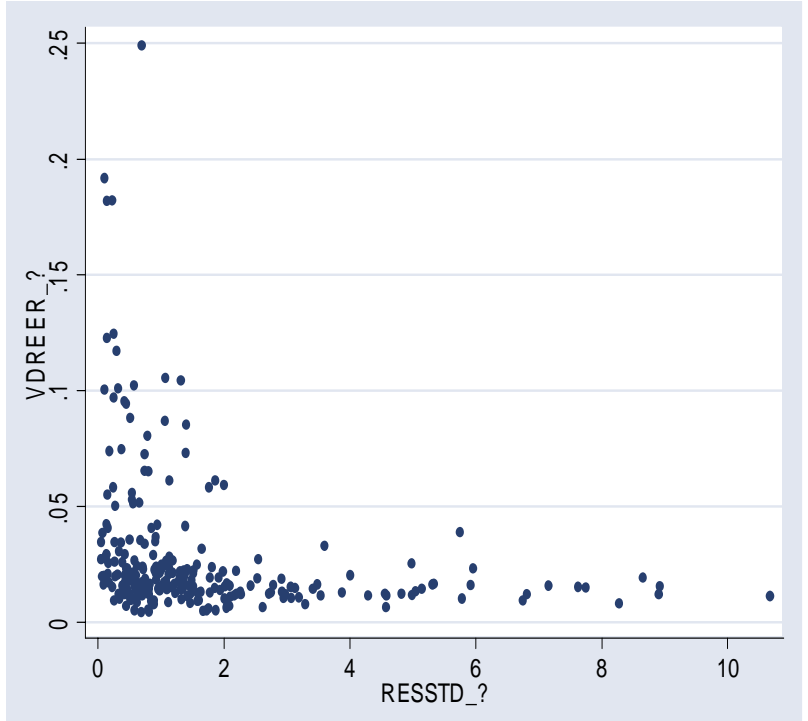

Panel B. With outliers removed

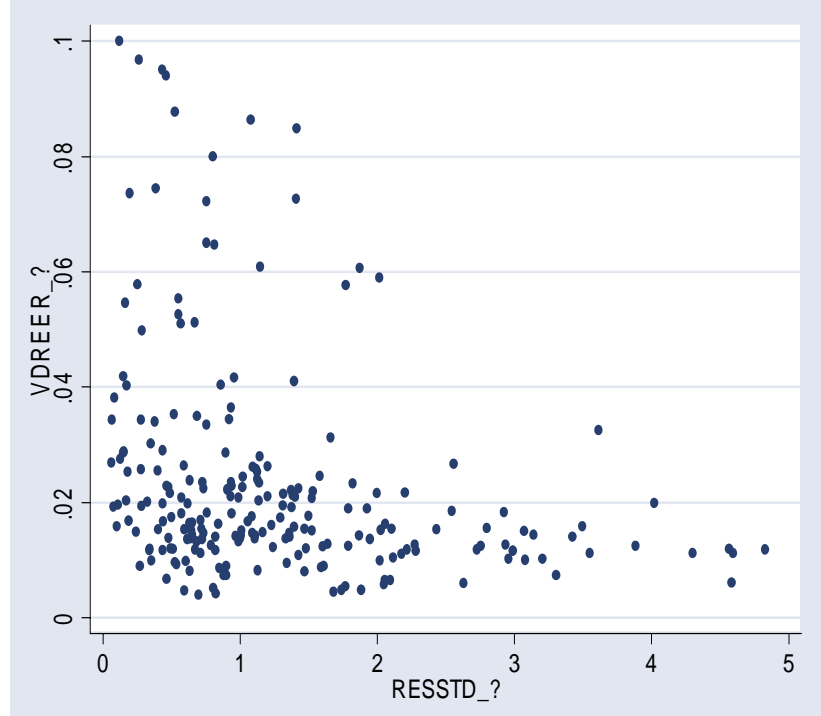

Note: Reserve adequacy (resstd) is measured as the ratio of gross reserves to short-term debt. The volatility of the real exchange rate (vdeer) is measured as the standard deviation of monthly changes in the natural logarithm of the real effective exchange rate.

The results of more formal econometric tests support this casual observation. On the basis of annual observations of 28 emerging market countries, we find that there is indeed strong evidence for a non-linear effect of the ratio of reserves to short-term debt on real effective exchange rate volatility. This relationship is robust to variations in sample length, the removal of outliers, the introduction of additional variables, and the use of econometric techniques to control for potential endogeneity, particularly that arising from choice of exchange rate regime. Moreover, the result still holds when foreign exchange intervention is taken into account, suggesting that signaling effects are important. 


\section{EXISTING EMPIRICAL WORK}

The literature on the determinants of the volatility of the exchange rate has reached a number of conclusions. ${ }^{8}$ First, there is much more volatility of exchange rates than can be explained by the volatility of macroeconomic fundamentals, even in models that assume sticky prices, sluggish money adjustment, and time-varying risk premia. ${ }^{9}$ Nonetheless, country differences in exchange rate volatility appear to be linked to a set of macroeconomic variables, as well as capital control measures, foreign exchange regime, and market structure. Moreover, balance sheet factors matter; these include the size of external debt and domestic market liquidity, as well as country size and level of development. In particular, the choice of exchange rate regime can reduce currency volatility, given that prices are normally stickier than the exchange rate. ${ }^{10}$

Two papers provide particularly useful insights. Devereux and Lane (2003) present a theoretical model where the choice of exchange rate flexibility, as measured by the volatility of nominal bilateral rates, is based on optimal currency area considerations with credit constraints. The theoretical results are then tested against a large cross-section of industrial and developing countries, using averages of monthly data from January 1995 to September 2000. The variables reflect the optimal currency area literature: bilateral trade as a share of GDP, the standard deviation of the bilateral growth rate differentials, and the log of the product of two countries' GDP. In addition, they include variables measuring the size of the domestic financial sector, bilateral external debt, and GDP per capita in purchasing power parity (PPP) terms. They find that all of these variables play a significant role in determining the bilateral volatility of the exchange rate.

Canales-Kriljenko and Habermeier (1999) test for the determinants of nominal exchange rate volatility on a cross-section of 85 developing and transition economies. ${ }^{11}$ In contrast to the panel regression framework applied in this paper, their use of a cross-section regression permitted the inclusion of a very large set of structural variables with little or no time variation, such as acceptance of IMF Article VIII restrictions, de jure exchange rate regime, and a set of measure

\footnotetext{
${ }^{8}$ A special strand of the literature on exchange rate volatility focuses on evaluating the stochastic process of short-term volatility. The upshot of this literature is that exchange rate volatility can be reasonably well described by an autoregressive process as captured, for example, by generalized autoregressive conditional heteroscedasticity (GARCH) models. While important for the measurement of volatility and the pricing of options, the literature does not throw much light on how volatility can be changed, or why it differs across of countries.

${ }^{9}$ See, for example, Devereux and Engel (2002), Rose (1994), and Bartolini and Bodnar (1996).

${ }^{10}$ See, for example, Hasan and Wallace (1996).

${ }^{11}$ Nominal exchange rate volatility was measured by the standard deviation of daily percentage changes in the nominal effective exchange rate during 2001.
} 
of exchange restrictions. On the basis of a model selection algorithm, they find that the most important macroeconomic determinants of nominal exchange rate volatility were: inflation, real GDP growth, fiscal deficit (in percent of GDP), and trade openness. Surprisingly, no measure of reserve adequacy was chosen by the model selection algorithm and none were, therefore, retained in the model.

\section{OUR APPROACH}

In order to investigate the role of reserve adequacy in reducing volatility of the real exchange rate, we analyze how such volatility is affected in turn by the volatility of fundamentals, variables describing policy actions to stabilize the exchange rate, and other variables that could be expected to influence market sentiment. Reserve levels may in principle relate both to policy choice (a high stock of reserves allows for more active use of currency intervention) and to market sentiment (higher reserves may signal the ability to intervene, if necessary, or raise market confidence by lowering the probability of a currency crisis). Thus, if after extensively controlling for fundamental determinants of exchange rate volatility and variables related to policy actions and market sentiment the reserve adequacy variable remains significant, the estimated effect is likely to operate through the impact of improved market sentiment rather than as the result of policy choice.

The empirical exercise presented here studies the determinants of the volatility of the real effective exchange rate in panel regressions for a selection of emerging markets over the period 1994-2002 (and for a smaller set over the 1986-2002 period). To the extent possible, the study includes variables used in previous studies as control factors. The econometric methodologies employed-system-generalized methods of moments (diff-GMM), and identification through heteroscedasticity $(\mathrm{IH}$ - - attempt to account for country-specific effects and to address potential endogeneity bias.

\section{A. Methodology ${ }^{12}$}

We estimate a linear model:

$$
y=\alpha+\beta X+\varepsilon
$$

where $y$ represents annual observations of real effective exchange rate volatility, $\alpha$ is a constant or a fixed effect term, $X$ is the set of explanatory variables, $\beta$ a vector of coefficients, and $\varepsilon$ is the error term.

As mentioned above, a primary challenge of this study was to overcome potential endogeneity (correlation of the error term $\varepsilon$ with the explanatory variables $X$ ) that would lead to biased

\footnotetext{
${ }^{12}$ We also run fixed-effect and difference-GMM regressions (results available upon request).
} 
estimates. In this paper, endogeneity can arise from an omitted-variable bias due, in particular, to the inability to properly control for the policy actions aimed at stabilizing the exchange rate. Arguably, in fact, the negative relationship between reserves and exchange rate volatility that is evident in the data (see Figure 1) could simply be driven by a third factor, such as the choice of exchange rate regime: if central banks choose to peg the exchange rate, they will need to hold a relatively large stock of reserves in order to smooth out exchange rate fluctuations or support a misaligned exchange rate.

In order to reduce the potential for such omitted-variable bias, the following approach is pursued:

- We include a dummy for the choice of the exchange rate regime (as determined by Reinhart and Rogoff, 2002) that should capture the direct effect of the regime on exchange rate volatility. Clearly, though, any dummy-however well-designed-is likely to be an imperfect proxy for the choice of exchange rate regime.

- We include several variables that have been found to affect the choice of exchange rate regime (see Devereux and Lane, 2003). These variables would complement the role of the previous dummy in controlling for the role of the regime.

- We include, in some specifications, a proxy for foreign exchange intervention, which should help capture policy actions aimed at stabilizing the exchange rate, especially for intermediate exchange rate regimes.

Endogeneity can, however, also arise from reverse causality. For a given exchange rate regime, the higher the volatility of the exchange rate, the more reserves a country might choose to hold. This effect of exchange rate volatility on reserves has a positive sign and would therefore tend to bias downward the estimated coefficient for the impact of reserves on exchange rate volatility, which is negative. In order to further control for endogeneity, we employ several tools:

- Reserves adequacy indicators are lagged one period in all regressions. This helps to reduce reverse causality effects, given that current exchange rate volatility is less likely to affect past levels of reserve adequacy.

- A system-GMM methodology is employed, which uses lags of levels and of first differences as instruments to correct for endogeneity. We allow for all available lags larger than 2 (the standard for endogenous variables) to be used.

- A new estimator, identification through heteroscedasticity (IH), developed by Rigobon (2003) is employed to address potential endogeneity problems. This estimator employs the heteroscedasticity present in the distribution of variables across years to estimate coefficients purged of endogeneity effects. 
Country-specific effects are also likely to be present in our exercise. For example, optimum currency area considerations would suggest that asymmetric shocks across countries could affect exchange rate volatility (see the evidence in Devereux and Lane, 2003). Also, institutional variables (acceptance of IMF Article VIII) and characteristics of the foreign exchange market have been found to play a role (Canales-Kriljenko and Habermeier, 1999). To the extent that these factors do not change radically over time, they are controlled for via the use of the system-GMM estimation, which accounts for country-specific effects.

\section{B. Sample}

The paper focuses on emerging market economies, since this set of countries has typically experienced the most marked currency volatility. The study looks at a group of 28 emerging market economies, which covers almost the entire IFC Global Index list as of August 2003. ${ }^{13}$ All of these countries have access to international capital markets.

The length and coverage of the sample was to a large extent dictated by the lack of availability of monthly data on external debt and monetary aggregates. ${ }^{14}$ We therefore constructed two samples:

- A primary sample to include a largest possible number of countries at the expense of the length of the time series: 28 countries for the 1994-2002 period.

- A secondary sample with fewer countries, but a longer times series: 22 countries for the 1986-2002 period (excluding the transition economies and Colombia).

In some regressions we will exclude countries that adopted a fixed exchange rate regime all the time or we will include only countries that were floating at least half of the time. ${ }^{15}$

\footnotetext{
${ }^{13}$ The economies included in the study are: Argentina, Brazil, Chile, China, Colombia, Czech Republic, Egypt, Hungary, India, Indonesia, Jordan, Korea, Malaysia, Mexico, Morocco, Nigeria, Pakistan, Peru, Philippines, Poland, Russia, Slovak Republic, South Africa, Sri Lanka, Thailand, Turkey, Venezuela, and Zimbabwe. Greece, Israel, and Taiwan Province of China, although present in the International Finance Corporation (IFC) list, were excluded from the sample due to insufficient data.

${ }^{14}$ In order to ensure a balanced sample, countries with insufficiently long data series were dropped from the respective sample.

${ }^{15}$ Fixers encompass: China, Egypt, Hungary, India, Jordan, Morocco, Pakistan, Peru, and Sri Lanka. Floaters encompass: Czech Republic, Indonesia, Korea, Mexico, Nigeria, Philippines, Russia, South Africa, Thailand, Turkey, Venezuela, and Zimbabwe.
} 


\section{Choice of Variables}

For the exact definition, notation, and source of the variables, see the appendix. Table 1 presents a basic statistical description of the variables.

The endogenous variable, exchange rate volatility (vdreer), is defined as the annual standard deviation of the monthly changes of the natural logarithm of the real effective exchange rate. This calculation gives one volatility observation per year. We chose to focus on the real effective exchange rate, since movements in the nominal exchange rate indices could be offset by variations in inflation differentials, and swings in bilateral rates could be offset by movement of other cross rates. The real effective exchange rate is likely to be more relevant than bilateral or nominal effective exchange rates for any real effects of exchange rate volatility.

The key explanatory variable, reserve adequacy, is defined as the ratio of reserve assets to short-term debt on a remaining maturity basis (resstd). ${ }^{16}$ While this is the reserve adequacy indicator employed in most empirical studies, we also employed other indicators, such as the ratio of reserve assets to imports (resi) and to GDP (resy). The reserve variables employed in the regressions are a non-linear transformation of the above ratios. This choice reflects the need to better capture the non-linear relationship evident in the data and also to identify a more economically meaningful relationship than the linear one, which would imply that, by raising reserves, a country could eventually achieve negative real exchange rate volatility. More precisely, the inverse of the exponential was applied to the reserve ratios (yielding invexprS, invexprI, and invexprY, respectively).

The control variables can be classified in four sets of varying size:

- Macroeconomic variables, such as growth ( gro ), inflation (infl), and fiscal balance to GDP ratio (fis). These variables capture confidence factors that may affect market sentiment and were used in the Canales-Kriljenko and Habermeier (1999) study. ${ }^{17}$

- Volatility of fundamentals, such as terms of trade and money supply. The first variable was employed in the Canales-Kriljenko and Habermeier study. The monetary volatility variable captures any influence from frequent changes in monetary stance, which according to the monetary theory of the exchange rate could be an important factor influencing the

${ }^{16}$ Both series are from the WEO databank, except for Korea which was based on staff estimates. For South Africa, short-term debt includes the forward book liabilities of the central bank.

${ }^{17}$ Data on bond market spreads or credit ratings were not included since it is documented that these variables are highly correlated with other explanatory variables such as reserve adequacy and fiscal deficits (see, for example, Christofides, Mulder, and Tiffin (2003)). 
volatility in the nominal exchange rate. ${ }^{18}$ Monetary volatility was constructed similarly to exchange rate volatility. Due to the lack of monthly data, terms of trade volatility was instead proxied by the absolute value of the change over the year.

- Variables related to the choice of exchange rate regime. First, a dummy was used for the choice of exchange rate regime (exdrum), based on a de facto classification of Reinhart and Rogoff (2002) ${ }^{19}$, which takes the value of 1 for purely floating, managed floating, and "freely falling" exchange rate regime, and 0 for de facto fixed exchange rate or crawling peg. ${ }^{20}$ Second, variables that are presumed to be related to the choice of exchange rate regime were introduced: trade openness (tropen), domestic financial deepness (findeap), external financial exposure (extfin), economic size (rpppwgt), level of economic development (rppppc), based on Devereux and Lane (2003).

- A proxy of foreign exchange market intervention. The measure (interv) was constructed by calculating the annual volatility of monthly changes in reserves, constructed in a similar way as exchange rate and monetary volatility. This variable may differ significantly from country specific definitions of foreign exchange intervention, as it abstracts from reserve accumulation rules and provides no information about the policy intentions underlying the reserve changes.

\section{RESUlTS}

Tables 2-9 present the results of the system-GMM regressions run on the 1994-2002 sample with 28 countries (Tables 2-4 and 6-8) and the 1986-2002 sample with 22 countries (Tables 5 and 9). Table 10 present the results from the IH methodology. Box 1 provides an explanation of how to interpret these tables.

In all regressions with the system-GMM methodology, the Hansen test does not reject the null hypothesis that the over-identifying restrictions are valid and the Arellano-Bond test does not reject the null hypothesis that there is no second-order autocorrelation (both test are generally way above the 10 percent probability-value threshold).

\footnotetext{
${ }^{18}$ See, for example, Dornbusch (1976) for an explanation of why monetary surprises combined with domestic price stickiness can result in large volatility in the exchange rate.

${ }^{19}$ Levy-Yeyati and Sturzeneger (2002) provide an alternative de facto classification based only on a combination of the volatility of the exchange rate and reserve changes.

${ }^{20}$ We also introduced a multiplicative variable constructed by multiplying reserve adequacy with the exchange rate dummy. This allows us to investigate whether the effect of reserves on volatility is different between floating and fixed exchange rate regimes.
} 


\section{The main results are as follows:}

- There is strong evidence that reduced volatility of the real effective exchange rate is associated with a higher level of reserves relative to short-term debt, as indicated by the positive coefficient on invexprS and a negative coefficient of logrestd_L.

- This result is robust to endogeneity controlled via the inclusion of variables influencing or capturing the choice of exchange rate regime, as well as econometric methods such as system-GMM and IH estimation.

- The effect appears to be mainly present for floaters: when invexprSD or logrestd_LD are entered in the regression (every second column in Tables 2 through 9), their coefficient is positive and significant, while the coefficient of invexprS or logrestd_L loses significance. ${ }^{21}$ Moreover, when fixers are excluded from the regressions (columns 1 and 2 of Tables 3 and 7) or only countries that were floating at least half of the time are included (column 3 and 4 of the same tables), the effect appears larger.

- The impact of reserve adequacy on exchange rate volatility does not appear to operate through intervention in the foreign exchange market: the coefficient on invexprS or logrestd_L remains significant even when a proxy for such intervention is included (columns 7 and 8 in all tables). This may not be surprising, since intervention is a characteristic of fixed exchange rate regimes and the set of explanatory variables already controls for the regime choice. The result may also be due to the admitted limitation of our proxy: a good proxy for intervention is not available for our sample.

- The impact of reserves adequacy on currency volatility also appears to be a recent phenomenon: when using the 1986-2002 sample, the effect is virtually absent (Tables 5 and 9), while when using the 1994-2002 sample the effect is very robust. ${ }^{22}$ The different results across samples is not due to the country composition of the samples, since the effect in 1994-2002 persists even when using the smaller sample of countries available for the 1986-2002 period, as in Table 2, columns 5 and 6.

In terms of other variables, five regressors-economic growth ( $\mathrm{gro}$ ), fiscal balance (fis), monetary volatility (mon), external debt (extfin), and country size (rpppwgt) - are robustly significant. The results are broadly consistent with the results obtained by Canales-Kriljenko

\footnotetext{
${ }^{21}$ When the sample of floaters (i.e., countries that on average floated for at least half of the time) is used, as in column 3 and 4 of Table 2, the distinction between invexprs and invexprsd is no longer particularly meaningful, and is it is not surprising that in column 4 invexprsd is not significant while invexprs remains significant.

${ }^{22}$ Regressions equivalent to those in Tables 3-4 and 7-8 run with the 1986-2002 sample (not reported for brevity) would also show insignificant results for the reserve adequacy measure.
} 
and Habermeier (1999) and Devereux and Lane (2003), although financial deepness (findeap) was among the variables found significant in these studies and is generally not significant in our regressions. On the other hand, monetary volatility (mon) — not included in the two studies mentioned-is highly significant, indicating that monetary policy is important for short-term real exchange rate volatility. ${ }^{23}$ The estimated coefficient on the fiscal balance is somewhat puzzling, since a positive sign implies that a higher deficit can be expected to result in lower volatility of the real effective exchange rate.

When comparing the results of this paper to the other studies, it is important to notice the relative importance of time-variance ("within variance”) versus cross-country variance ("between variance”). Table 1 shows that for many variables the "within" variance is at least as important as the "between" variance. Indeed, in the case of the dependent variable the "within" standard deviation is nearly twice as large as the "between" standard deviation. It is not surprising, therefore, that our results do not coincide with those of the other two studies, which employ a cross-sectional approach.

23 The fact that the volatility of the terms of trade was not significant may simply reflect the lack of good intra-year data (tot was constructed as the absolute value of the annual change in the terms of trade). 


\section{Box 1. How to Interpret Tables 2-10}

The focus of the paper is on the role of the reserve indicators in reducing exchange rate volatility. Because these indicators are non-linear transformations of the reserve adequacy indicators discussed above, particular care needs be taken when interpreting the signs of the coefficients. Tables 2-5 and 10 use the inverse of the exponential of the reserve measure, while Tables 6-9 use a (natural) logarithmic transformation of the reserve measure. Also, these measures are multiplied by the flexible exchange rate dummy (when presenting a $D$ at the end of the name):

- Hence, a positive coefficient on invexprS implies a negative non-linear effect of the reserves to short-term debt ratio (given that invexprS declines when the reserve ratio increases) on exchange rate volatility. Conversely, the same effect is captured by a negative logrestd_L.

- A positive coefficient for invexprSD (i.e., invexprS multiplied by the exchange rate dummy, which takes the value of 1 for a floating managed floating regime) in the second column indicates a "larger" effect of the reserves to short-term debt ratio under the floating exchange rate regime. Again, the same effect is captured by a negative logrestd_LD.

Regarding the headings in Tables 2-9: "Main" refers to the main specification; "Only sig." refers to retention of only variables that are significant in the main specification; "No outliers" refers to the elimination of countries that appeared as outliers with high leverage (in order to ensure that the results are not driven by a few observations), as visible in Figures 2 and 3 for regressions with fixed effects in the two samples; "W/ interv" refers to the inclusion of the intervention proxy; "No fixers" refers to the elimination of countries that were pure fixers (exchange rate dummy always equal to 0) throughout the sample; "Only floaters" refers to retention of only countries that were floating at least half of the time (exchange rate dummy always larger than 0.5 , on average); "86 sample” refers to the retention only of the 22 countries that are present in the 1986-2002 sample (in order to ensure comparability of results across the two samples).

Table 10 reports $\mathrm{IH}$ estimations for the regressions with all control variables and with only significant ones for both samples, reporting only the coefficient estimate on invexprS. Due to the nature of the methodology, the exchange rate dummy was dropped from the set of variables (even when included, the results do not vary significantly) 


\section{QUANTIFYING THE ESTIMATED EFFECTS}

The relationship is non-linear. Hence, the impact of an increase in reserve adequacy on the short-term volatility of the real exchange rate depends on the initial level of the reserve ratio: the higher the level of reserves, the smaller the effect of a given increase in reserves on the variability of the real exchange rate. Also, for any level of the reserve ratio, the effect of any increase is smaller than the effect of a decrease. The two non-linear specifications (the inverse of the exponential of reserves and the logarithm of reserves) indicate a different magnitude of the effect due to the different functional form; the flatter shape of the latter obviously implies a somewhat smaller impact.

To illustrate the magnitude of the effect, consider the case in which the average country in the 1994-2002 sample would halve its ratio of reserves to short-term debt from 170 percent (see Table 1) to 85 percent:

- $\quad$ On the basis of the exponential specification with a coefficient of 0.02 (roughly the one for invexprS in the main regressions in Table 2), such a country would experience an increase in exchange rate volatility (i.e., in the standard deviation of the monthly changes in the real exchange rate), by almost 20 percent. $^{24}$

- $\quad$ This implies that the probability of a change in the real exchange rate that is larger than two times its initial standard deviation would double from 5 to 10 percent.

- $\quad$ On the basis of the logaritmic specification with a coefficient of negative 0.004 (roughly the one for logresstd_L in the main regressions in Table 6), the effect is almost half that with the exponential specification.

When considering the effect for floaters, the appropriate coefficient is about 0.04 (the sum of invexprS and invexprsd, in Tables 2 and 3), which would tend to indicate an effect that is twice as large. However, the average reserve ratio is lower and exchange rate volatility higher for floaters than for the whole sample (respectively, 100 percent and 4.4 percent). When taking these values into account, the effect for floaters of halving the reserve ratio turns out to be similar to the one described above for the whole sample.

Regarding the control variables, the significant effects would indicate that, on average:

- A 1 percentage point increase in monetary volatility would increase volatility by 0.7-0.8 percentage-points (or by about 20 percent of average sample volatility in 2002). This suggests that three quarters of monetary volatility is translated into exchange rate volatility.

${ }^{24}$ Reflecting the non-linearity, the effect of an increase in the reserve ratio of equal magnitude (i.e. from 170 percent to 255 percent) would imply a decline in volatility by less than 10 percent. 
It is interesting to note that the effect is larger (close to 1) when pure fixers are excluded from the sample (Table 2, columns 1-4).

- A 1 percentage point increase in real GDP growth would reduce volatility by 0.2 percentage points (or by about 6 percent).

- A 10 percentage point increase in external debt relative to GDP growth would increase volatility by 0.6 percentage points (or by about 20 percent).

\section{STANDARD Methodologies}

As a matter of illustration, we also present the results of using the standard ordinary least squares (OLS) and fixed-effect estimation methods, both in a bivariate and multivariate setup (see Table 11). As explained earlier, these methods are considered as less reliable than the system-GMM because they do not control for endogeneity. The significant coefficient on the reserves variable in the bivariate OLS regressions simply confirms what can be visibly discerned in Figure 1, and bivariate fixed-effect regressions indicate that the result cannot be solely explained in terms of country-specific constant terms. The multivariate OLS and fixed effect regressions shows that the result is robust to controlling for other determinants of exchange rate volatility and in particular to the inclusion of factors (the exchange rate regime) that may drive both the level of reserves and exchange rate volatility.

We also conducted fixed-effects and difference-GMM estimations for most specifications in Tables 2 through 9. In these estimations, not reported for reasons of brevity, we found again a very robust effect of reserves on the volatility of the real exchange rate. However, these methods were providing less consistent results in terms of whether the effect applies to fixers or floaters or whether it changes over time.

\section{CONCLUSIONS}

The paper finds strong evidence of a negative non-linear effect of reserves on the short-term volatility of the real effective exchange rate, for a sample of emerging market countries. This effect is found to be robust to endogeneity, particularly to controlling for the role of exchange rate regime, which could influence both the choice of reserves as well as the volatility of the exchange rate. Endogeneity was controlled for by including variables influencing or capturing the choice of exchange rate regime, as well as econometric methods such as system-GMM and $\mathrm{IH}$ estimation and lagging reserve adequacy measures.

The effect is not particularly large. If the average country in the 1994-2002 sample halved its ratio of reserves to short-term debt, it could experience an increase in exchange rate volatility of up to 20 percent. This implies that the probability of a change in the real exchange rate that is larger than two times its initial standard deviation would almost double. 
The effect appears mainly associated with floaters. The estimated coefficient is higher when the sample is restricted to only floaters. Also, when a different slope for floaters is allowed, the coefficient for the whole sample loses significance while the one for floaters is strongly significant. Even though estimates are different, when taking into account also the sample differences in reserve ratio and exchange rate volatility, the overall impact of changing the reserve ratio on volatility appears similar for floaters and for the whole sample.

In terms of the channel through which this effect operates, only tentative conclusions can be made at this stage. The effect does not appear to operate via the use of reserves to intervene in the foreign exchange market, but rather through signaling a greater potential for foreign exchange intervention in a crisis situation or a generally increased "comfort level." Further research would be needed to identify the channels through which the higher reserve levels are working. For example, a proxy for exchange market intervention that better captures policy intentions could provide further insights into this important issue.

Other policy actions may, however, be at least as powerful as reserve accumulation in reducing real exchange rate volatility. In particular, monetary volatility and external debt seem to be powerful determinants of real exchange rate volatility, suggesting that a credible and stability-oriented monetary policy combined with external debt management would be important elements of any policy package aimed at reducing unwanted real exchange rate volatility.

The results of this paper should not be interpreted as unequivocally advocating an increase in reserve levels. First, the non-linear nature of the relationship implies that the benefits would mainly be confined to countries with relatively low reserves. ${ }^{25}$ And second, the benefits of increased reserves in terms of reduced currency volatility-as argued in this paper-as well as lower interest rates, reduced risk of currency crisis, and a more predictable business environment—as argued in previous literature-would need to be compared with the drawbacks, most notably the costs associated with holding reserves.

\footnotetext{
${ }^{25}$ In a recent comprehensive study, Clark and others (2003) find some evidence in favor of a negative effect of the exchange rate on trade, but this relationship is not found to be robust to the inclusion of time-varying country effects in the panel specification. However, the elimination of the time variation may not be particularly appropriate for investigating the effect of exchange rate volatility, given that such volatility exhibits substantial within-country variability (as shown in Table 1).
} 


\section{DEFINITION OF VARIABLES}

All series are from the IMF's World Economic Outlook (WEO) database unless otherwise specified.

\section{References}

vdreer Standard deviation of monthly changes of the natural logarithm of the real effective exchange rate (REER) (source: IMF Internal Notice System).

Reserve variables (lagged one period in all regressions)

resstd The ratio of reserve assets to short-term debt on a remaining maturity basis. Short-term debt for Korea is based on staff estimates. Short-term debt for South Africa includes the forward book liabilities of the central bank.

resi The ratio of reserve assets to average monthly imports of goods and nonfactor services (GNFS).

resy The ratio of reserve assets to nominal GDP.

invexprS/I/Y Inverse of the exponential of the above three measures, respectively. Variables reflecting macroeconomic factors and volatility of fundamentals

fis The fiscal balance as ratio of nominal GDP.

infl The CPI inflation rate (annual percent change).

gro Real GDP growth (annual percent change).

mon Annual standard deviation of monthly changes of broad money (source: IMF International Financial Statistics).

tot The absolute value of the difference in annual growth rates of GNFS import and export price deflators

\section{Variables that affect the choice of exchange rate regime}

tropen Trade openness, measured as the ratio of the sum of annual GFNS exports and imports to nominal GDP.

findeap

An indicator domestic financial deepness: the ratio of broad money to nominal GDP. 
extfin

rрpppc

rpppwgt
An indicator external financial exposure: the ratio of total external debt to GDP.

An indicator of the country's level of economic development: per capita constant-price GDP measured at the purchasing power parity (PPP) exchange rate.

A size indicator: GDP measured at PPP exchange rates and deflated by the U.S. GDP deflator.

\section{Exchange rate regime (dummy)}

exdrum

A dummy describing the exchange rate regime: floating, managed float, or freely falling $=1$; de facto peg or crawling peg $=0$. Based on Reinhart and Rogoff (2002) dataset, which is available until 2001. Datapoints for 2002 are equal to 2001, with the exception of Venezuela, which was classified as a 1 .

\section{Foreign exchange intervention proxy}

interv

A proxy of foreign exchange intervention. The standard deviation of monthly difference in the ratio of reserves to GDP. 
Table 1. Descriptives: 1994-2002, 28 Emerging Markets

\begin{tabular}{lcccc}
\hline Variable & Mean & SD & Between SD & Within SD \\
\hline vdreer & 0.028 & 0.032 & 0.017 & 0.028 \\
resstd & 1.668 & 1.836 & 1.629 & 0.899 \\
resi & 5.470 & 2.822 & 2.464 & 1.444 \\
resy & 0.145 & 0.087 & 0.077 & 0.043 \\
gro & 0.032 & 0.044 & 0.021 & 0.039 \\
fis & -0.038 & 0.038 & 0.026 & 0.028 \\
infl & 0.148 & 0.271 & 0.150 & 0.226 \\
tot & 0.050 & 0.065 & 0.041 & 0.051 \\
tropen & 0.691 & 0.414 & 0.405 & 0.111 \\
mon & 0.022 & 0.017 & 0.012 & 0.013 \\
exrdum & 0.377 & 0.486 & 0.332 & 0.360 \\
findeap & 0.555 & 0.325 & 0.320 & 0.078 \\
extfin & 0.511 & 0.230 & 0.193 & 0.131 \\
rppppc & 62.079 & 35.900 & 36.043 & 5.578 \\
rpppwgt & 4.976 & 8.225 & 8.183 & 1.677 \\
interv & 0.075 & 0.062 & 0.039 & 0.049 \\
\hline
\end{tabular}

Note: SD, standard deviation. 
Table 2. Volatility of Growth in REER, Basic Table: 1994-2002 (28 Emerging Market Economies)

\begin{tabular}{|c|c|c|c|c|c|c|c|c|}
\hline & Main & Main & Only sig. & Only sig. & No outliers & No outliers & $\mathrm{W} /$ interv & $\mathrm{W} /$ interv \\
\hline invexpRS & $\begin{array}{l}0.016 \\
(2.18)^{* *}\end{array}$ & $\begin{array}{l}0.004 \\
(0.41)\end{array}$ & $\begin{array}{l}0.021 \\
(2.38)^{* *}\end{array}$ & $\begin{array}{l}0.010 \\
(1.10)\end{array}$ & $\begin{array}{l}0.011 \\
(1.49)\end{array}$ & $\begin{array}{l}0.003 \\
(0.35)\end{array}$ & $\begin{array}{l}0.016 \\
(2.07)^{* *}\end{array}$ & $\begin{array}{l}0.005 \\
(0.46)\end{array}$ \\
\hline invexpRSD & & $\begin{array}{l}0.031 \\
(2.62)^{* * *}\end{array}$ & & $\begin{array}{l}0.018 \\
(2.60)^{* * *}\end{array}$ & & $\begin{array}{l}0.023 \\
(1.90)^{*}\end{array}$ & & $\begin{array}{l}0.028 \\
(2.45)^{* *}\end{array}$ \\
\hline gro_ & $\begin{array}{l}-0.208 \\
(4.06)^{* * *}\end{array}$ & $\begin{array}{l}-0.212 \\
(4.40)^{* * *}\end{array}$ & $\begin{array}{l}-0.244 \\
(3.55)^{* * *}\end{array}$ & $\begin{array}{l}-0.233 \\
(3.95)^{* * *}\end{array}$ & $\begin{array}{l}-0.162 \\
(3.86)^{* * *}\end{array}$ & $\begin{array}{l}-0.160 \\
(4.04)^{* * *}\end{array}$ & $\begin{array}{l}-0.203 \\
(4.15)^{* * *}\end{array}$ & $\begin{array}{l}-0.208 \\
(4.46)^{* * *}\end{array}$ \\
\hline fis_ & $\begin{array}{l}0.082 \\
(2.07)^{* *}\end{array}$ & $\begin{array}{l}0.074 \\
(1.84)^{*}\end{array}$ & $\begin{array}{l}0.101 \\
(2.34)^{* *}\end{array}$ & $\begin{array}{l}0.089 \\
(1.89)^{*}\end{array}$ & $\begin{array}{l}0.007 \\
(0.17)\end{array}$ & $\begin{array}{l}0.012 \\
(0.25)\end{array}$ & $\begin{array}{l}0.088 \\
(2.23)^{* *}\end{array}$ & $\begin{array}{l}0.078 \\
(1.96)^{*}\end{array}$ \\
\hline infl_ & $\begin{array}{l}-0.006 \\
(0.60)\end{array}$ & $\begin{array}{l}-0.008 \\
(0.72)\end{array}$ & & & $\begin{array}{l}0.001 \\
(0.09)\end{array}$ & $\begin{array}{l}0.000 \\
(0.02)\end{array}$ & $\begin{array}{l}-0.005 \\
(0.49)\end{array}$ & $\begin{array}{l}-0.007 \\
(0.61)\end{array}$ \\
\hline tot_ & $\begin{array}{l}-0.005 \\
(0.13)\end{array}$ & $\begin{array}{l}-0.013 \\
(0.34)\end{array}$ & & & $\begin{array}{l}-0.003 \\
(0.07)\end{array}$ & $\begin{array}{l}-0.013 \\
(0.30)\end{array}$ & $\begin{array}{l}-0.005 \\
(0.15)\end{array}$ & $\begin{array}{l}-0.013 \\
(0.32)\end{array}$ \\
\hline tropen_ & $\begin{array}{l}-0.009 \\
(1.21)\end{array}$ & $\begin{array}{l}-0.009 \\
(1.19)\end{array}$ & & & $\begin{array}{l}-0.009 \\
(1.28)\end{array}$ & $\begin{array}{l}-0.009 \\
(1.26)\end{array}$ & $\begin{array}{l}-0.011 \\
(1.32)\end{array}$ & $\begin{array}{l}-0.010 \\
(1.23)\end{array}$ \\
\hline mon_ & $\begin{array}{l}0.775 \\
(2.88)^{* * *}\end{array}$ & $\begin{array}{l}0.785 \\
(2.97)^{* * *}\end{array}$ & $\begin{array}{l}0.749 \\
(4.00)^{* * *}\end{array}$ & $\begin{array}{l}0.717 \\
(3.78)^{* * *}\end{array}$ & $\begin{array}{l}0.410 \\
(2.87)^{* * *}\end{array}$ & $\begin{array}{l}0.442 \\
(3.02)^{* * *}\end{array}$ & $\begin{array}{l}0.760 \\
(2.88)^{* * *}\end{array}$ & $\begin{array}{l}0.768 \\
(2.95)^{* * *}\end{array}$ \\
\hline exrdum_ & $\begin{array}{l}0.007 \\
(1.89)^{*}\end{array}$ & $\begin{array}{l}-0.006 \\
(1.14)\end{array}$ & & & $\begin{array}{l}0.008 \\
(2.39)^{* *}\end{array}$ & $\begin{array}{l}-0.003 \\
(0.41)\end{array}$ & $\begin{array}{l}0.007 \\
(1.94)^{*}\end{array}$ & $\begin{array}{l}-0.005 \\
(0.96)\end{array}$ \\
\hline findeap_ & $\begin{array}{l}0.003 \\
(0.26)\end{array}$ & $\begin{array}{l}-0.001 \\
(0.06)\end{array}$ & & & $\begin{array}{l}0.003 \\
(0.33)\end{array}$ & $\begin{array}{l}0.000 \\
(0.00)\end{array}$ & $\begin{array}{l}0.001 \\
(0.15)\end{array}$ & $\begin{array}{l}-0.001 \\
(0.12)\end{array}$ \\
\hline extfin_ & $\begin{array}{l}0.060 \\
(3.54)^{* * *}\end{array}$ & $\begin{array}{l}0.060 \\
(3.57)^{* * *}\end{array}$ & $\begin{array}{l}0.053 \\
(3.64)^{* * *}\end{array}$ & $\begin{array}{l}0.050 \\
(3.59)^{* * *}\end{array}$ & $\begin{array}{l}0.036 \\
(1.77)^{*}\end{array}$ & $\begin{array}{l}0.037 \\
(1.83)^{*}\end{array}$ & $\begin{array}{l}0.057 \\
(3.32)^{* * *}\end{array}$ & $\begin{array}{l}0.059 \\
(3.46)^{* * *}\end{array}$ \\
\hline rррррс _ & $\begin{array}{l}0.000 \\
(0.94)\end{array}$ & $\begin{array}{l}0.000 \\
(1.41)\end{array}$ & & & $\begin{array}{l}0.000 \\
(1.17)\end{array}$ & $\begin{array}{l}0.000 \\
(1.44)\end{array}$ & $\begin{array}{l}0.000 \\
(0.83)\end{array}$ & $\begin{array}{l}0.000 \\
(1.34)\end{array}$ \\
\hline rpppwgt_ & $\begin{array}{l}0.001 \\
(2.75)^{* * *}\end{array}$ & $\begin{array}{l}0.001 \\
(2.81)^{* * *}\end{array}$ & $\begin{array}{l}0.001 \\
(3.40)^{* * *}\end{array}$ & $\begin{array}{l}0.001 \\
(3.31)^{* * *}\end{array}$ & $\begin{array}{l}0.001 \\
(1.71)^{*}\end{array}$ & $\begin{array}{l}0.001 \\
(1.79)^{*}\end{array}$ & $\begin{array}{l}0.001 \\
(2.86)^{* * *}\end{array}$ & $\begin{array}{l}0.001 \\
(2.90)^{* * *}\end{array}$ \\
\hline interv_ & & & & & & & $\begin{array}{l}0.049 \\
(1.48)\end{array}$ & $\begin{array}{l}0.030 \\
(0.99)\end{array}$ \\
\hline Constant & $\begin{array}{l}-0.021 \\
(1.38)\end{array}$ & $\begin{array}{l}-0.017 \\
(1.14)\end{array}$ & $\begin{array}{l}-0.017 \\
(1.62)\end{array}$ & $\begin{array}{l}-0.015 \\
(1.45)\end{array}$ & $\begin{array}{l}-0.005 \\
(0.36)\end{array}$ & $\begin{array}{l}-0.003 \\
(0.22)\end{array}$ & $\begin{array}{l}-0.021 \\
(1.34)\end{array}$ & $\begin{array}{l}-0.017 \\
(1.14)\end{array}$ \\
\hline Observations & 252 & 252 & 252 & 252 & 216 & 216 & 251 & 251 \\
\hline No. of countries & 28 & 28 & 28 & 28 & 24 & 24 & 28 & 28 \\
\hline
\end{tabular}

Note: Robust $z$ statistics in parentheses. REER, real effective exchange rate.

* Significant at $10 \%$; ** significant at $5 \%$; ** significant at $1 \%$.

Note: Robust z statistics in parentheses. REER, real effective exchange rate.

* Significant at 10\%; ** significant at 5\%; *** significant at $1 \%$. 
Table 3. Volatility of Growth in REER, Sample Changes: 1994-2002 (28 Emerging Market Economies)

\begin{tabular}{|c|c|c|c|c|c|c|}
\hline & No fixers & No fixers & Only floaters & Only floaters & 86 sample & 86 sample \\
\hline \multirow[t]{2}{*}{ invexpRS } & 0.021 & -0.002 & 0.038 & 0.051 & 0.011 & -0.003 \\
\hline & $(1.79)^{*}$ & $(0.10)$ & $(4.19)^{* * *}$ & $(2.61)^{* * *}$ & (1.39) & $(0.28)$ \\
\hline \multirow[t]{2}{*}{ invexpRSD } & & 0.039 & & -0.018 & & 0.038 \\
\hline & & $(2.56)^{* *}$ & & $(0.78)$ & & $(2.93) * * *$ \\
\hline \multirow[t]{2}{*}{ gro_ } & -0.190 & -0.202 & -0.177 & -0.173 & -0.200 & -0.205 \\
\hline & $(3.89) * * *$ & $(4.37)^{* * *}$ & $(3.38)^{* * *}$ & $(3.15)^{* * *}$ & $(3.45)^{* * *}$ & $(3.80)^{* * *}$ \\
\hline \multirow[t]{2}{*}{ fis } & 0.103 & 0.097 & 0.119 & 0.122 & 0.099 & 0.092 \\
\hline & $(3.22) * * *$ & $(2.97) * * *$ & $(3.28)^{* * *}$ & $(3.39)^{* * *}$ & $(2.42) * *$ & $(2.15)^{* *}$ \\
\hline \multirow[t]{2}{*}{$i n f l_{-}$} & -0.007 & -0.008 & -0.012 & -0.012 & 0.001 & -0.000 \\
\hline & $(0.56)$ & $(0.66)$ & (1.29) & (1.38) & $(0.10)$ & $(0.00)$ \\
\hline \multirow[t]{2}{*}{ tot_ } & -0.022 & -0.033 & -0.011 & -0.006 & -0.016 & -0.032 \\
\hline & $(0.59)$ & $(0.85)$ & $(0.32)$ & $(0.18)$ & $(0.39)$ & $(0.78)$ \\
\hline \multirow[t]{2}{*}{ tropen_ } & -0.009 & -0.010 & -0.047 & -0.048 & -0.004 & -0.003 \\
\hline & $(1.01)$ & $(1.12)$ & $(5.04)^{* * *}$ & $(4.79)^{* * *}$ & $(0.35)$ & $(0.30)$ \\
\hline \multirow[t]{2}{*}{ mon_ } & 0.987 & 1.018 & 1.118 & 1.105 & 0.698 & 0.727 \\
\hline & $(3.02) * * *$ & $(3.31)^{* * *}$ & $(3.80)^{* * *}$ & $(3.65)^{* * *}$ & $(2.15)^{* *}$ & $(2.34)^{* *}$ \\
\hline \multirow[t]{2}{*}{ exrdum_ } & 0.003 & -0.014 & 0.009 & 0.018 & 0.008 & -0.010 \\
\hline & $(0.66)$ & $(2.22)^{* *}$ & $(1.90)^{*}$ & (1.43) & $(1.41)$ & (1.33) \\
\hline \multirow[t]{2}{*}{ findeap_ } & 0.010 & 0.008 & 0.017 & 0.016 & -0.006 & -0.010 \\
\hline & $(0.64)$ & $(0.58)$ & $(2.08)^{* *}$ & $(2.09)^{* *}$ & $(0.44)$ & $(0.86)$ \\
\hline \multirow[t]{2}{*}{ extfin_ } & 0.083 & 0.086 & 0.120 & 0.121 & 0.062 & 0.063 \\
\hline & $(6.10)^{* * *}$ & $(7.02)^{* * *}$ & $(7.89)^{* * *}$ & $(7.62)^{* * *}$ & $(3.54)^{* * *}$ & $(3.66) * * *$ \\
\hline \multirow[t]{2}{*}{ rppppc_ } & 0.000 & 0.000 & 0.000 & 0.000 & 0.000 & 0.000 \\
\hline & $(2.05)^{* *}$ & $(2.52)^{* *}$ & $(6.47)^{* * *}$ & $(6.64)^{* * *}$ & $(0.89)$ & $(1.26)$ \\
\hline \multirow[t]{2}{*}{$r p p p w g t_{-}$} & 0.002 & 0.002 & -0.000 & -0.000 & 0.001 & 0.001 \\
\hline & $(1.95)^{*}$ & $(2.22)^{* *}$ & $(0.36)$ & $(0.56)$ & $(2.42)^{* *}$ & $(2.55)^{* *}$ \\
\hline \multirow[t]{2}{*}{ Constant } & -0.051 & -0.044 & -0.075 & -0.081 & -0.018 & -0.013 \\
\hline & $(2.48)^{* *}$ & $(2.32)^{* *}$ & $(6.53)^{* * *}$ & $(5.76)^{* * *}$ & $(1.05)$ & $(0.80)$ \\
\hline Observations & 171 & 171 & 108 & 108 & 198 & 198 \\
\hline No. of countries & 19 & 19 & 12 & 12 & 22 & 22 \\
\hline
\end{tabular}

Note: Robust $\mathrm{z}$ statistics in parentheses. REER, real effective exchange rate.

* Significant at $10 \%$; ** significant at $5 \%$; *** significant at $1 \%$. 
Table 4. Volatility of Growth in REER, Other Reserve Measures: 1994-2002 (28 Emerging Market Economies)

\begin{tabular}{|c|c|c|c|c|c|c|c|c|c|c|c|c|}
\hline & Main & Main & $\mathrm{W} /$ interv & $\mathrm{W} /$ interv & No fixers & No fixers & Main & Main & W/ interv & $\mathrm{W} /$ interv & No fixers & No fixers \\
\hline invexpRI & $\begin{array}{l}0.012 \\
(0.87)\end{array}$ & $\begin{array}{l}0.004 \\
(0.18)\end{array}$ & $\begin{array}{l}0.012 \\
(0.85)\end{array}$ & $\begin{array}{l}0.008 \\
(0.37)\end{array}$ & $\begin{array}{l}0.011 \\
(0.50)\end{array}$ & $\begin{array}{l}-0.013 \\
(0.42)\end{array}$ & & & & & & \\
\hline invexpRID & & $\begin{array}{l}0.015 \\
(0.51)\end{array}$ & & $\begin{array}{l}0.004 \\
(0.14)\end{array}$ & & $\begin{array}{l}0.032 \\
(0.98)\end{array}$ & & & & & & \\
\hline invexpRY & & & & & & & $\begin{array}{l}0.111 \\
(2.06)^{* *}\end{array}$ & $\begin{array}{l}0.079 \\
(1.40)\end{array}$ & $\begin{array}{l}0.096 \\
(1.87)^{*}\end{array}$ & $\begin{array}{l}0.070 \\
(1.30)\end{array}$ & $\begin{array}{l}0.107 \\
(1.36)\end{array}$ & $\begin{array}{l}0.008 \\
(0.10)\end{array}$ \\
\hline invexpRYD & & & & & & & & $\begin{array}{l}0.049 \\
(0.87)\end{array}$ & & $\begin{array}{l}0.044 \\
(0.79)\end{array}$ & & $\begin{array}{l}0.122 \\
(2.38)^{* *}\end{array}$ \\
\hline $\mathrm{gro}_{-}$ & $\begin{array}{l}-0.208 \\
(3.94)^{* * *}\end{array}$ & $\begin{array}{l}-0.207 \\
(4.09)^{* * *}\end{array}$ & $\begin{array}{l}-0.203 \\
(3.95)^{* * * *}\end{array}$ & $\begin{array}{l}-0.202 \\
(4.02)^{* * * *}\end{array}$ & $\begin{array}{l}-0.193 \\
(3.69)^{* * * *}\end{array}$ & $\begin{array}{l}-0.201 \\
(3.89)^{* * * *}\end{array}$ & $\begin{array}{l}-0.190 \\
(4.28)^{* * *}\end{array}$ & $\begin{array}{l}-0.191 \\
(4.48)^{* * *}\end{array}$ & $\begin{array}{l}-0.186 \\
(4.27)^{* * * *}\end{array}$ & $\begin{array}{l}-0.189 \\
(4.43)^{* * * *}\end{array}$ & $\begin{array}{l}-0.171 \\
(3.88)^{* * *}\end{array}$ & $\begin{array}{l}-0.189 \\
(4.35)^{* * *}\end{array}$ \\
\hline$f i s_{-}$ & $\begin{array}{l}0.083 \\
(2.01)^{* *}\end{array}$ & $\begin{array}{l}0.078 \\
(1.92)^{*}\end{array}$ & $\begin{array}{l}0.089 \\
(2.17)^{* *}\end{array}$ & $\begin{array}{l}0.085 \\
(2.11)^{* *}\end{array}$ & $\begin{array}{l}0.105 \\
(3.11)^{* * *}\end{array}$ & $\begin{array}{l}0.102 \\
(3.02)^{* * *}\end{array}$ & $\begin{array}{l}0.082 \\
(2.19)^{* *}\end{array}$ & $\begin{array}{l}0.079 \\
(2.13)^{* *}\end{array}$ & $\begin{array}{l}0.089 \\
(2.38)^{* *}\end{array}$ & $\begin{array}{l}0.082 \\
(2.26)^{* *}\end{array}$ & $\begin{array}{l}0.098 \\
(3.29)^{* * *}\end{array}$ & $\begin{array}{l}0.098 \\
(3.41)^{* * *}\end{array}$ \\
\hline infl_ & $\begin{array}{l}-0.005 \\
(0.43)\end{array}$ & $\begin{array}{l}-0.005 \\
(0.48)\end{array}$ & $\begin{array}{l}-0.005 \\
(0.44)\end{array}$ & $\begin{array}{l}-0.004 \\
(0.39)\end{array}$ & $\begin{array}{l}-0.007 \\
(0.58)\end{array}$ & $\begin{array}{l}-0.007 \\
(0.54)\end{array}$ & $\begin{array}{l}-0.010 \\
(0.99)\end{array}$ & $\begin{array}{l}-0.009 \\
(0.92)\end{array}$ & $\begin{array}{l}-0.006 \\
(0.58)\end{array}$ & $\begin{array}{l}-0.007 \\
(0.68)\end{array}$ & $\begin{array}{l}-0.009 \\
(0.72)\end{array}$ & $\begin{array}{l}-0.010 \\
(0.89)\end{array}$ \\
\hline tot_ & $\begin{array}{l}-0.007 \\
(0.18)\end{array}$ & $\begin{array}{l}-0.005 \\
(0.14)\end{array}$ & $\begin{array}{l}-0.009 \\
(0.23)\end{array}$ & $\begin{array}{l}-0.006 \\
(0.18)\end{array}$ & $\begin{array}{l}-0.025 \\
(0.69)\end{array}$ & $\begin{array}{l}-0.026 \\
(0.73)\end{array}$ & $\begin{array}{l}0.007 \\
(0.18)\end{array}$ & $\begin{array}{l}0.015 \\
(0.42)\end{array}$ & $\begin{array}{l}0.005 \\
(0.13)\end{array}$ & $\begin{array}{l}0.012 \\
(0.34)\end{array}$ & $\begin{array}{l}-0.009 \\
(0.23)\end{array}$ & $\begin{array}{l}-0.009 \\
(0.24)\end{array}$ \\
\hline tropen_ & $\begin{array}{l}-0.009 \\
(1.14)\end{array}$ & $\begin{array}{l}-0.009 \\
(1.16)\end{array}$ & $\begin{array}{l}-0.011 \\
(1.26)\end{array}$ & $\begin{array}{l}-0.011 \\
(1.25)\end{array}$ & $\begin{array}{l}-0.012 \\
(1.23)\end{array}$ & $\begin{array}{l}-0.012 \\
(1.27)\end{array}$ & $\begin{array}{l}-0.005 \\
(0.54)\end{array}$ & $\begin{array}{l}-0.005 \\
(0.67)\end{array}$ & $\begin{array}{l}-0.007 \\
(0.76)\end{array}$ & $\begin{array}{l}-0.007 \\
(0.80)\end{array}$ & $\begin{array}{l}-0.006 \\
(0.66)\end{array}$ & $\begin{array}{l}-0.009 \\
(1.06)\end{array}$ \\
\hline mon $_{-}$ & $\begin{array}{l}0.748 \\
(2.75)^{* * *}\end{array}$ & $\begin{array}{l}0.748 \\
(2.74)^{* * *}\end{array}$ & $\begin{array}{l}0.743 \\
(2.79)^{* * *}\end{array}$ & $\begin{array}{l}0.739 \\
(2.75)^{* * *}\end{array}$ & $\begin{array}{l}0.947 \\
(2.87)^{* * *}\end{array}$ & $\begin{array}{l}0.960 \\
(2.86)^{* * *}\end{array}$ & $\begin{array}{l}0.725 \\
(2.61)^{* * *}\end{array}$ & $\begin{array}{l}0.701 \\
(2.51)^{* *}\end{array}$ & $\begin{array}{l}0.707 \\
(2.59)^{* * *}\end{array}$ & $\begin{array}{l}0.689 \\
(2.49)^{* *}\end{array}$ & $\begin{array}{l}0.910 \\
(2.68)^{* * *}\end{array}$ & $\begin{array}{l}0.893 \\
(2.60)^{* * *}\end{array}$ \\
\hline exrdum_ & $\begin{array}{l}0.009 \\
(2.11)^{* *}\end{array}$ & $\begin{array}{l}0.008 \\
(1.77)^{*}\end{array}$ & $\begin{array}{l}0.009 \\
(2.17)^{* *}\end{array}$ & $\begin{array}{l}0.009 \\
(1.90)^{*}\end{array}$ & $\begin{array}{l}0.004 \\
(0.91)\end{array}$ & $\begin{array}{l}0.003 \\
(0.56)\end{array}$ & $\begin{array}{l}0.008 \\
(2.18)^{* *}\end{array}$ & $\begin{array}{l}-0.034 \\
(0.71)\end{array}$ & $\begin{array}{l}0.008 \\
(2.25)^{* *}\end{array}$ & $\begin{array}{l}-0.030 \\
(0.62)\end{array}$ & $\begin{array}{l}0.005 \\
(1.07)\end{array}$ & $\begin{array}{l}-0.103 \\
(2.36)^{* *}\end{array}$ \\
\hline findeap_ & $\begin{array}{l}-0.003 \\
(0.31)\end{array}$ & $\begin{array}{l}-0.003 \\
(0.29)\end{array}$ & $\begin{array}{l}-0.004 \\
(0.41)\end{array}$ & $\begin{array}{l}-0.004 \\
(0.39)\end{array}$ & $\begin{array}{l}0.008 \\
(0.50)\end{array}$ & $\begin{array}{l}0.009 \\
(0.56)\end{array}$ & $\begin{array}{l}0.009 \\
(0.76)\end{array}$ & $\begin{array}{l}0.007 \\
(0.63)\end{array}$ & $\begin{array}{l}0.006 \\
(0.61)\end{array}$ & $\begin{array}{l}0.005 \\
(0.50)\end{array}$ & $\begin{array}{l}0.018 \\
(1.05)\end{array}$ & $\begin{array}{l}0.012 \\
(0.74)\end{array}$ \\
\hline extfin_ & $\begin{array}{l}0.064 \\
(3.58)^{* * *}\end{array}$ & $\begin{array}{l}0.063 \\
(3.57)^{* * *}\end{array}$ & $\begin{array}{l}0.061 \\
(3.36)^{* * *}\end{array}$ & $\begin{array}{l}0.061 \\
(3.36)^{* * *}\end{array}$ & $\begin{array}{l}0.087 \\
(6.03)^{* * *}\end{array}$ & $\begin{array}{l}0.086 \\
(6.02)^{* * *}\end{array}$ & $\begin{array}{l}0.069 \\
(4.08)^{* * *}\end{array}$ & $\begin{array}{l}0.067 \\
(3.96)^{* * *}\end{array}$ & $\begin{array}{l}0.066 \\
(3.77)^{* * *}\end{array}$ & $\begin{array}{l}0.064 \\
(3.74)^{* * *}\end{array}$ & $\begin{array}{l}0.091 \\
(7.44)^{* * *}\end{array}$ & $\begin{array}{l}0.093 \\
(8.53)^{* * *}\end{array}$ \\
\hline rрpрpс & $\begin{array}{l}0.000 \\
(1.00)\end{array}$ & $\begin{array}{l}0.000 \\
(0.99)\end{array}$ & $\begin{array}{l}0.000 \\
(0.87)\end{array}$ & $\begin{array}{l}0.000 \\
(0.87)\end{array}$ & $\begin{array}{l}0.000 \\
(1.48)\end{array}$ & $\begin{array}{l}0.000 \\
(1.38)\end{array}$ & $\begin{array}{l}0.000 \\
(1.36)\end{array}$ & $\begin{array}{l}0.000 \\
(1.33)\end{array}$ & $\begin{array}{l}0.000 \\
(1.23)\end{array}$ & $\begin{array}{l}0.000 \\
(1.23)\end{array}$ & $\begin{array}{l}0.000 \\
(1.89)^{*}\end{array}$ & $\begin{array}{l}0.000 \\
(2.18)^{* *}\end{array}$ \\
\hline rpppwgt_ & $\begin{array}{l}0.001 \\
(2.81)^{* * *}\end{array}$ & $\begin{array}{l}0.001 \\
(2.77)^{* * *}\end{array}$ & $\begin{array}{l}0.001 \\
(2.96)^{* * *} \\
0.053 \\
(1.53)\end{array}$ & $\begin{array}{l}0.001 \\
(2.91)^{* * *} \\
0.049 \\
(1.41)\end{array}$ & $\begin{array}{l}0.002 \\
(2.07)^{* *}\end{array}$ & $\begin{array}{l}0.002 \\
(2.10)^{* *}\end{array}$ & $\begin{array}{l}0.001 \\
(2.40)^{* *}\end{array}$ & $\begin{array}{l}0.001 \\
(2.47)^{* *}\end{array}$ & $\begin{array}{l}0.001 \\
(2.63)^{* * *} \\
0.049 \\
(1.44)\end{array}$ & $\begin{array}{l}0.001 \\
(2.65)^{* * *} \\
0.035 \\
(1.14)\end{array}$ & $\begin{array}{l}0.002 \\
(1.73)^{*}\end{array}$ & $\begin{array}{l}0.002 \\
(1.74)^{*}\end{array}$ \\
\hline Constant & $\begin{array}{l}-0.015 \\
(1.01)\end{array}$ & $\begin{array}{l}-0.014 \\
(0.98)\end{array}$ & $\begin{array}{l}-0.015 \\
(1.00)\end{array}$ & $\begin{array}{l}-0.015 \\
(0.98)\end{array}$ & $\begin{array}{l}-0.038 \\
(2.14)^{* *}\end{array}$ & $\begin{array}{l}-0.036 \\
(2.07)^{* *}\end{array}$ & $\begin{array}{l}-0.124 \\
(2.22)^{* *}\end{array}$ & $\begin{array}{l}-0.093 \\
(1.64)\end{array}$ & $\begin{array}{l}-0.110 \\
(2.03)^{* *}\end{array}$ & $\begin{array}{l}-0.085 \\
(1.53)\end{array}$ & $\begin{array}{l}-0.145 \\
(1.89)^{*}\end{array}$ & $\begin{array}{l}-0.053 \\
(0.66)\end{array}$ \\
\hline Observations & 252 & 252 & 251 & 251 & 171 & 171 & 252 & 252 & 251 & 251 & 171 & 171 \\
\hline No. of countries & 28 & 28 & 28 & 28 & 19 & 19 & 28 & 28 & 28 & 28 & 19 & 19 \\
\hline
\end{tabular}

Note: Robust $\mathrm{z}$ statistics in parentheses. REER, real effective exchange rate.

* significant at $10 \%$; ** significant at $5 \%$; *** significant at $1 \%$. 
Table 5. Volatility of Growth in REER, Basic Table: 1986-2002 (22 Emerging Market Economies)

\begin{tabular}{|c|c|c|c|c|c|c|c|c|}
\hline & Main & Main & Only sig. & Only sig. & No outliers & No outliers & $\mathrm{W} /$ interv & $\mathrm{W} /$ interv \\
\hline \multirow[t]{2}{*}{ invexpRS } & 0.006 & -0.001 & 0.019 & 0.001 & 0.003 & 0.001 & 0.006 & -0.002 \\
\hline & $(1.23)$ & $(0.18)$ & $(3.27)^{* * *}$ & $(0.25)$ & $(0.68)$ & $(0.26)$ & (1.14) & $(0.27)$ \\
\hline \multirow[t]{2}{*}{ invexpRSD } & & 0.018 & & 0.029 & & 0.004 & & 0.018 \\
\hline & & $(1.18)$ & & $(3.67)^{* * *}$ & & $(0.26)$ & & $(1.16)$ \\
\hline \multirow[t]{2}{*}{ gro } & -0.180 & -0.177 & -0.209 & -0.170 & -0.126 & -0.125 & -0.181 & -0.178 \\
\hline & $(3.57)^{* * *}$ & $(3.62)^{* * *}$ & $(3.67)^{* * *}$ & $(3.65)^{* * *}$ & $(2.85)^{* * *}$ & $(2.91)^{* * *}$ & $(3.63)^{* * *}$ & $(3.67)^{* * *}$ \\
\hline \multirow[t]{2}{*}{ fis } & 0.053 & 0.047 & 0.081 & 0.041 & 0.015 & 0.015 & 0.053 & 0.047 \\
\hline & (1.46) & (1.23) & $(2.45)^{* *}$ & $(1.02)$ & $(0.33)$ & $(0.32)$ & $(1.47)$ & (1.26) \\
\hline \multirow[t]{2}{*}{ infl_ } & 0.005 & 0.004 & & & 0.018 & 0.017 & 0.005 & 0.004 \\
\hline & $(0.67)$ & $(0.61)$ & & & $(2.18)^{* *}$ & $(2.03)^{* *}$ & $(0.67)$ & (0.59) \\
\hline \multirow[t]{2}{*}{ tot_ } & 0.017 & 0.015 & & & -0.013 & -0.013 & 0.016 & 0.012 \\
\hline & $(0.60)$ & $(0.49)$ & & & $(0.43)$ & $(0.44)$ & $(0.54)$ & $(0.41)$ \\
\hline \multirow[t]{2}{*}{ tropen_ } & -0.006 & -0.006 & & & -0.010 & -0.010 & -0.005 & -0.006 \\
\hline & $(0.59)$ & $(0.66)$ & & & $(1.32)$ & $(1.31)$ & $(0.53)$ & $(0.60)$ \\
\hline \multirow[t]{2}{*}{$\mathrm{mon}_{-}$} & 0.511 & 0.515 & 0.520 & 0.545 & 0.501 & 0.504 & 0.513 & 0.518 \\
\hline & $(3.02)^{* * *}$ & $(3.04)^{* * *}$ & $(3.56)^{* * *}$ & $(4.43)^{* * *}$ & $(2.69)^{* * *}$ & $(2.69)^{* * *}$ & $(3.00)^{* * *}$ & $(3.04)^{* * *}$ \\
\hline \multirow[t]{2}{*}{ exrdum_ } & 0.018 & 0.009 & & & 0.012 & 0.010 & 0.018 & 0.009 \\
\hline & $(4.55)^{* * *}$ & (1.09) & & & $(3.80)^{* * *}$ & (1.31) & $(4.44)^{* * *}$ & $(1.05)$ \\
\hline \multirow[t]{2}{*}{ findeap_ } & 0.004 & 0.003 & & & 0.012 & 0.012 & 0.004 & 0.003 \\
\hline & $(0.47)$ & $(0.33)$ & & & $(1.89)^{*}$ & $(1.90)^{*}$ & $(0.42)$ & $(0.32)$ \\
\hline \multirow[t]{2}{*}{ extfin_ } & 0.027 & 0.028 & 0.027 & 0.026 & 0.012 & 0.012 & 0.027 & 0.028 \\
\hline & $(1.99)^{* *}$ & $(1.99)^{* *}$ & $(1.98)^{* *}$ & $(1.97)^{* *}$ & $(0.94)$ & $(0.92)$ & $(2.08)^{* *}$ & $(2.12)^{* *}$ \\
\hline \multirow[t]{2}{*}{ rрpppc } & -0.000 & -0.000 & & & -0.000 & -0.000 & -0.000 & -0.000 \\
\hline & $(0.56)$ & $(0.55)$ & & & $(0.23)$ & $(0.23)$ & $(0.56)$ & $(0.52)$ \\
\hline \multirow[t]{2}{*}{ rpppwgt_ } & 0.001 & 0.001 & 0.001 & 0.001 & 0.000 & 0.000 & 0.001 & 0.001 \\
\hline & $(1.87)^{*}$ & $(1.76)^{*}$ & $(3.29)^{* * *}$ & $(2.88)^{* * *}$ & $(0.78)$ & $(0.76)$ & $(1.88)^{*}$ & $(1.76)^{*}$ \\
\hline \multirow[t]{2}{*}{ interv_ } & & & & & & & -0.004 & -0.010 \\
\hline & & & & & & & $(0.21)$ & $(0.57)$ \\
\hline \multirow[t]{2}{*}{ Constant } & 0.000 & 0.004 & 0.001 & 0.001 & 0.005 & 0.005 & 0.001 & 0.004 \\
\hline & $(0.03)$ & $(0.35)$ & $(0.11)$ & $(0.09)$ & $(0.49)$ & $(0.57)$ & $(0.05)$ & $(0.36)$ \\
\hline Observations & 374 & 374 & 374 & 374 & 323 & 323 & 371 & 371 \\
\hline No. of countries & 22 & 22 & 22 & 22 & 19 & 19 & 22 & 22 \\
\hline
\end{tabular}

Note: Robust z statistics in parentheses. REER, real effective exchange rate.

* Significant at $10 \%$; ** significant at $5 \%$; *** significant at $1 \%$. 
Table 6. Volatility of Growth in REER, Basic Table: 1994-2002 (28 Emerging Market Economies)

\begin{tabular}{|c|c|c|c|c|c|c|c|c|}
\hline & Main & Main & Only sig. & Only sig. & No outliers & No outliers & $\mathrm{W} /$ interv & W/ interv \\
\hline logresstd_L & $\begin{array}{l}-0.004 \\
(1.66)^{*}\end{array}$ & $\begin{array}{l}-0.001 \\
(0.28)\end{array}$ & $\begin{array}{l}-0.005 \\
(1.84)^{*}\end{array}$ & $\begin{array}{l}-0.002 \\
(0.66)\end{array}$ & $\begin{array}{l}-0.003 \\
(1.28)\end{array}$ & $\begin{array}{l}-0.001 \\
(0.29)\end{array}$ & $\begin{array}{l}-0.004 \\
(1.56)\end{array}$ & $\begin{array}{l}-0.001 \\
(0.30)\end{array}$ \\
\hline logresstd_LD & & $\begin{array}{l}-0.008 \\
(2.64)^{* * *}\end{array}$ & & $\begin{array}{l}-0.007 \\
(1.77)^{*}\end{array}$ & & $\begin{array}{l}-0.006 \\
(1.90)^{*}\end{array}$ & & $\begin{array}{l}-0.007 \\
(2.44)^{* *}\end{array}$ \\
\hline gro_ & $\begin{array}{l}-0.206 \\
(4.01)^{* * *}\end{array}$ & $\begin{array}{l}-0.210 \\
(4.34)^{* * *}\end{array}$ & $\begin{array}{l}-0.243 \\
(3.54)^{* * *}\end{array}$ & $\begin{array}{l}-0.241 \\
(3.79)^{* * *}\end{array}$ & $\begin{array}{l}-0.163 \\
(3.83)^{* * *}\end{array}$ & $\begin{array}{l}-0.160 \\
(4.02)^{* * *}\end{array}$ & $\begin{array}{l}-0.202 \\
(4.12)^{* * *}\end{array}$ & $\begin{array}{l}-0.206 \\
(4.41)^{* * *}\end{array}$ \\
\hline fis & $\begin{array}{l}0.081 \\
(2.05)^{* *}\end{array}$ & $\begin{array}{l}0.074 \\
(1.81)^{*}\end{array}$ & $\begin{array}{l}0.098 \\
(2.28)^{* *}\end{array}$ & $\begin{array}{l}0.090 \\
(2.04)^{* *}\end{array}$ & $\begin{array}{l}0.005 \\
(0.12)\end{array}$ & $\begin{array}{l}0.008 \\
(0.17)\end{array}$ & $\begin{array}{l}0.087 \\
(2.22)^{* *}\end{array}$ & $\begin{array}{l}0.077 \\
(1.93)^{*}\end{array}$ \\
\hline infl_ & $\begin{array}{l}-0.006 \\
(0.59)\end{array}$ & $\begin{array}{l}-0.008 \\
(0.77)\end{array}$ & & & $\begin{array}{l}0.001 \\
(0.09)\end{array}$ & $\begin{array}{l}0.000 \\
(0.00)\end{array}$ & $\begin{array}{l}-0.005 \\
(0.49)\end{array}$ & $\begin{array}{l}-0.007 \\
(0.64)\end{array}$ \\
\hline tot_ & $\begin{array}{l}-0.006 \\
(0.17)\end{array}$ & $\begin{array}{l}-0.015 \\
(0.37)\end{array}$ & & & $\begin{array}{l}-0.006 \\
(0.13)\end{array}$ & $\begin{array}{l}-0.014 \\
(0.33)\end{array}$ & $\begin{array}{l}-0.007 \\
(0.19)\end{array}$ & $\begin{array}{l}-0.014 \\
(0.35)\end{array}$ \\
\hline tropen_ & $\begin{array}{l}-0.010 \\
(1.23)\end{array}$ & $\begin{array}{l}-0.009 \\
(1.17)\end{array}$ & & & $\begin{array}{l}-0.009 \\
(1.30)\end{array}$ & $\begin{array}{l}-0.008 \\
(1.26)\end{array}$ & $\begin{array}{l}-0.011 \\
(1.34)\end{array}$ & $\begin{array}{l}-0.010 \\
(1.21)\end{array}$ \\
\hline $\mathrm{mon}_{-}$ & $\begin{array}{l}0.774 \\
(2.85)^{* * *}\end{array}$ & $\begin{array}{l}0.791 \\
(3.00)^{* * *}\end{array}$ & $\begin{array}{l}0.769 \\
(3.95)^{* * *}\end{array}$ & $\begin{array}{l}0.775 \\
(4.15)^{* * *}\end{array}$ & $\begin{array}{l}0.409 \\
(2.85)^{* * *}\end{array}$ & $\begin{array}{l}0.443 \\
(3.00)^{* * *}\end{array}$ & $\begin{array}{l}0.758 \\
(2.85)^{* * *}\end{array}$ & $\begin{array}{l}0.772 \\
(2.95)^{* * *}\end{array}$ \\
\hline exrdum_ & $\begin{array}{l}0.008 \\
(1.90)^{*}\end{array}$ & $\begin{array}{l}0.005 \\
(1.44)\end{array}$ & & & $\begin{array}{l}0.008 \\
(2.39)^{* *}\end{array}$ & $\begin{array}{l}0.006 \\
(1.78)^{*}\end{array}$ & $\begin{array}{l}0.008 \\
(1.96)^{*}\end{array}$ & $\begin{array}{l}0.005 \\
(1.54)\end{array}$ \\
\hline findeap_ & $\begin{array}{l}0.002 \\
(0.17)\end{array}$ & $\begin{array}{l}-0.002 \\
(0.19)\end{array}$ & & & $\begin{array}{l}0.002 \\
(0.27)\end{array}$ & $\begin{array}{l}-0.001 \\
(0.08)\end{array}$ & $\begin{array}{l}0.000 \\
(0.05)\end{array}$ & $\begin{array}{l}-0.002 \\
(0.27)\end{array}$ \\
\hline extfin_ & $\begin{array}{l}0.061 \\
(3.61)^{* * *}\end{array}$ & $\begin{array}{l}0.062 \\
(3.66)^{* * *}\end{array}$ & $\begin{array}{l}0.055 \\
(3.72)^{* * *}\end{array}$ & $\begin{array}{l}0.053 \\
(3.59)^{* * *}\end{array}$ & $\begin{array}{l}0.036 \\
(1.80)^{*}\end{array}$ & $\begin{array}{l}0.038 \\
(1.89)^{*}\end{array}$ & $\begin{array}{l}0.058 \\
(3.38)^{* * *}\end{array}$ & $\begin{array}{l}0.060 \\
(3.53)^{* * *}\end{array}$ \\
\hline rррррс _ & $\begin{array}{l}0.000 \\
(0.91)\end{array}$ & $\begin{array}{l}0.000 \\
(1.33)\end{array}$ & & & $\begin{array}{l}0.000 \\
(1.13)\end{array}$ & $\begin{array}{l}0.000 \\
(1.43)\end{array}$ & $\begin{array}{l}0.000 \\
(0.79)\end{array}$ & $\begin{array}{l}0.000 \\
(1.24)\end{array}$ \\
\hline rpppwgt_ & $\begin{array}{l}0.001 \\
(2.74)^{* * *}\end{array}$ & $\begin{array}{l}0.001 \\
(2.80)^{* * *}\end{array}$ & $\begin{array}{l}0.001 \\
(3.41)^{* * *}\end{array}$ & $\begin{array}{l}0.001 \\
(3.04)^{* * *}\end{array}$ & $\begin{array}{l}0.001 \\
(1.71)^{*}\end{array}$ & $\begin{array}{l}0.001 \\
(1.83)^{*}\end{array}$ & $\begin{array}{l}0.001 \\
(2.84)^{* * *}\end{array}$ & $\begin{array}{l}0.001 \\
(2.87)^{* * *}\end{array}$ \\
\hline interv_ & & & & & & & $\begin{array}{l}0.050 \\
(1.51)\end{array}$ & $\begin{array}{l}0.031 \\
(1.01)\end{array}$ \\
\hline Constant & $\begin{array}{l}-0.015 \\
(1.02)\end{array}$ & $\begin{array}{l}-0.015 \\
(1.13)\end{array}$ & $\begin{array}{l}-0.011 \\
(0.97)\end{array}$ & $\begin{array}{l}-0.011 \\
(1.06)\end{array}$ & $\begin{array}{l}-0.001 \\
(0.08)\end{array}$ & $\begin{array}{l}-0.003 \\
(0.18)\end{array}$ & $\begin{array}{l}-0.015 \\
(1.00)\end{array}$ & $\begin{array}{l}-0.015 \\
(1.10)\end{array}$ \\
\hline Observations & 252 & 252 & 252 & 252 & 216 & 216 & 251 & 251 \\
\hline No. of countries & 28 & 28 & 28 & 28 & 24 & 24 & 28 & 28 \\
\hline
\end{tabular}

Note: Robust z statistics in parentheses. REER, real effective exchange rate.

* Significant at $10 \%$; ** significant at $5 \%$; *** significant at $1 \%$. 
Table 7. Volatility of Growth in REER, Sample Changes: 1994-2002 (28 Emerging Market Economies)

\begin{tabular}{|c|c|c|c|c|c|c|}
\hline & No fixers & No fixers & Only floaters & Only floaters & 86 sample & 86 sample \\
\hline \multirow[t]{2}{*}{ logresstd_L } & -0.005 & 0.002 & -0.009 & -0.012 & -0.002 & 0.001 \\
\hline & $(1.70)^{*}$ & $(0.33)$ & $(3.22)^{* * *}$ & $(1.71)^{*}$ & $(0.99)$ & $(0.34)$ \\
\hline \multirow[t]{2}{*}{ logresstd_LD } & & -0.011 & & 0.003 & & -0.010 \\
\hline & & $(2.66)^{* * *}$ & & $(0.43)$ & & $(2.93)^{* * *}$ \\
\hline \multirow[t]{2}{*}{ gro_ } & -0.188 & -0.202 & -0.174 & -0.170 & -0.202 & -0.206 \\
\hline & $(3.80)^{* * *}$ & $(4.27)^{* * *}$ & $(3.34)^{* * *}$ & $(3.16)^{* * *}$ & $(3.45)^{* * *}$ & $(3.78)^{* * *}$ \\
\hline \multirow[t]{2}{*}{$f i s_{-}$} & 0.100 & 0.094 & 0.112 & 0.114 & 0.098 & 0.091 \\
\hline & $(3.12)^{* * *}$ & $(2.89) * * *$ & $(2.93)^{* * *}$ & $(2.98)^{* * *}$ & $(2.39)^{* *}$ & $(2.14)^{* *}$ \\
\hline \multirow[t]{2}{*}{ infl_ } & -0.008 & -0.009 & -0.013 & -0.013 & 0.001 & -0.000 \\
\hline & $(0.63)$ & $(0.72)$ & $(1.46)$ & (1.55) & $(0.10)$ & $(0.03)$ \\
\hline \multirow[t]{2}{*}{ tot_ } & -0.024 & -0.034 & -0.014 & -0.011 & -0.017 & -0.031 \\
\hline & $(0.66)$ & (0.89) & $(0.40)$ & $(0.34)$ & $(0.41)$ & $(0.77)$ \\
\hline \multirow[t]{2}{*}{ tropen_ } & -0.009 & -0.010 & -0.047 & -0.048 & -0.005 & -0.003 \\
\hline & $(1.00)$ & (1.12) & $(5.05)^{* * *}$ & $(4.91)^{* * *}$ & $(0.37)$ & $(0.27)$ \\
\hline \multirow[t]{2}{*}{ mon_ } & 0.980 & 1.015 & 1.107 & 1.097 & 0.693 & 0.728 \\
\hline & $(2.98)^{* * *}$ & $(3.35)^{* * *}$ & $(3.71)^{* * *}$ & $(3.61)^{* * *}$ & $(2.13)^{* *}$ & $(2.33)^{* *}$ \\
\hline \multirow[t]{2}{*}{ exrdum_ } & 0.003 & 0.000 & 0.009 & 0.010 & 0.009 & 0.005 \\
\hline & $(0.63)$ & $(0.11)$ & $(1.72)^{*}$ & $(1.72)^{*}$ & $(1.48)$ & $(0.95)$ \\
\hline \multirow[t]{2}{*}{ findeap_ } & 0.008 & 0.007 & 0.016 & 0.015 & -0.006 & -0.011 \\
\hline & $(0.56)$ & $(0.53)$ & $(1.75)^{*}$ & $(1.73)^{*}$ & $(0.49)$ & (0.99) \\
\hline \multirow[t]{2}{*}{ extfin_ } & 0.085 & 0.086 & 0.122 & 0.123 & 0.062 & 0.064 \\
\hline & $(6.38)^{* * *}$ & $(7.40)^{* * *}$ & $(8.35)^{* * *}$ & $(7.99)^{* * *}$ & $(3.52)^{* * *}$ & $(3.69)^{* * *}$ \\
\hline \multirow[t]{2}{*}{ rрpрpс } & 0.000 & 0.000 & 0.000 & 0.000 & 0.000 & 0.000 \\
\hline & $(1.97)^{* *}$ & $(2.29)^{* *}$ & $(6.42)^{* * *}$ & $(6.65)^{* * *}$ & $(0.81)$ & $(1.23)$ \\
\hline \multirow[t]{2}{*}{ rpppwgt_ } & 0.002 & 0.002 & -0.000 & -0.000 & 0.001 & 0.001 \\
\hline & $(1.99)^{* *}$ & $(2.29)^{* *}$ & $(0.14)$ & $(0.26)$ & $(2.37)^{* *}$ & $(2.55)^{* *}$ \\
\hline \multirow[t]{2}{*}{ Constant } & -0.042 & -0.043 & -0.060 & -0.060 & -0.013 & -0.014 \\
\hline & $(2.26)^{* *}$ & $(2.91)^{* * *}$ & $(5.03)^{* * *}$ & $(4.86)^{* * *}$ & $(0.83)$ & $(0.96)$ \\
\hline Observations & 171 & 171 & 108 & 108 & 198 & 198 \\
\hline No. of countries & 19 & 19 & 12 & 12 & 22 & 22 \\
\hline
\end{tabular}

Note: Robust z statistics in parentheses. REER, real effective exchange rate.

* Significant at $10 \%$; ${ }^{* *}$ significant at $5 \%$; *** significant at $1 \%$. 
Table 8. Volatility of Growth in REER, Other Reserve Measures: 1994-2002 (28 Emerging Market Economies)

\begin{tabular}{|c|c|c|c|c|c|c|c|c|c|c|c|c|}
\hline & Main & Main & W/ interv & W/ interv & No fixers & No fixers & Main & Main & W/ interv & W/ interv & No fixers & No fixers \\
\hline logresi_L & $\begin{array}{l}-0.003 \\
(1.23)\end{array}$ & $\begin{array}{l}-0.004 \\
(1.24)\end{array}$ & $\begin{array}{l}-0.004 \\
(1.29)\end{array}$ & $\begin{array}{l}-0.005 \\
(1.40)\end{array}$ & $\begin{array}{l}-0.004 \\
(0.91)\end{array}$ & $\begin{array}{l}-0.006 \\
(0.98)\end{array}$ & & & & & & \\
\hline logresi_LD & & $\begin{array}{l}0.003 \\
(0.51)\end{array}$ & & $\begin{array}{l}0.006 \\
(0.94)\end{array}$ & & $\begin{array}{l}0.003 \\
(0.35)\end{array}$ & & & & & & \\
\hline logresy_L & & & & & & & $\begin{array}{l}-0.008 \\
(2.32)^{* *}\end{array}$ & $\begin{array}{l}-0.006 \\
(1.34)\end{array}$ & $\begin{array}{l}-0.007 \\
(2.10)^{* *}\end{array}$ & $\begin{array}{l}-0.005 \\
(1.24)\end{array}$ & $\begin{array}{l}-0.009 \\
(1.69) *\end{array}$ & $\begin{array}{l}-0.000 \\
(0.05)\end{array}$ \\
\hline logresy_LD & & & & & & & & $\begin{array}{l}-0.005 \\
(0.92)\end{array}$ & & $\begin{array}{l}-0.004 \\
(0.73)\end{array}$ & & $\begin{array}{l}-0.011 \\
(2.14)^{* *}\end{array}$ \\
\hline gro_ & $\begin{array}{l}-0.208 \\
(4.02)^{* * *}\end{array}$ & $\begin{array}{l}-0.204 \\
(3.79)^{* * *}\end{array}$ & $\begin{array}{l}-0.202 \\
(4.09)^{* * *}\end{array}$ & $\begin{array}{l}-0.199 \\
(3.80)^{* * *}\end{array}$ & $\begin{array}{l}-0.187 \\
(3.76)^{* * *}\end{array}$ & $\begin{array}{l}-0.187 \\
(3.69)^{* * *}\end{array}$ & $\begin{array}{l}-0.188 \\
(3.92)^{* * *}\end{array}$ & $\begin{array}{l}-0.189 \\
(4.17)^{* * *}\end{array}$ & $\begin{array}{l}-0.184 \\
(3.94)^{* * *}\end{array}$ & $\begin{array}{l}-0.186 \\
(4.08)^{* * *}\end{array}$ & $\begin{array}{l}-0.161 \\
(3.59)^{* * *}\end{array}$ & $\begin{array}{l}-0.184 \\
(3.99)^{* * *}\end{array}$ \\
\hline fis & $\begin{array}{l}0.084 \\
(2.05)^{* *}\end{array}$ & $\begin{array}{l}0.082 \\
(1.98)^{* *}\end{array}$ & $\begin{array}{l}0.091 \\
(2.24)^{* *}\end{array}$ & $\begin{array}{l}0.090 \\
(2.22)^{* *}\end{array}$ & $\begin{array}{l}0.102 \\
(3.13)^{* * *}\end{array}$ & $\begin{array}{l}0.101 \\
(3.00)^{* * *}\end{array}$ & $\begin{array}{l}0.077 \\
(1.95)^{*}\end{array}$ & $\begin{array}{l}0.075 \\
(1.92)^{*}\end{array}$ & $\begin{array}{l}0.085 \\
(2.16)^{* *}\end{array}$ & $\begin{array}{l}0.079 \\
(2.07)^{* *}\end{array}$ & $\begin{array}{l}0.094 \\
(3.04)^{* * *}\end{array}$ & $\begin{array}{l}0.096 \\
(3.14)^{* * *}\end{array}$ \\
\hline infl_ & $\begin{array}{l}-0.006 \\
(0.57)\end{array}$ & $\begin{array}{l}-0.005 \\
(0.42)\end{array}$ & $\begin{array}{l}-0.006 \\
(0.54)\end{array}$ & $\begin{array}{l}-0.003 \\
(0.30)\end{array}$ & $\begin{array}{l}-0.009 \\
(0.73)\end{array}$ & $\begin{array}{l}-0.008 \\
(0.66)\end{array}$ & $\begin{array}{l}-0.011 \\
(1.11)\end{array}$ & $\begin{array}{l}-0.012 \\
(1.19)\end{array}$ & $\begin{array}{l}-0.008 \\
(0.80)\end{array}$ & $\begin{array}{l}-0.009 \\
(0.93)\end{array}$ & $\begin{array}{l}-0.012 \\
(1.03)\end{array}$ & $\begin{array}{l}-0.013 \\
(1.08)\end{array}$ \\
\hline tot_ & $\begin{array}{l}-0.003 \\
(0.09)\end{array}$ & $\begin{array}{l}0.002 \\
(0.06)\end{array}$ & $\begin{array}{l}-0.005 \\
(0.13)\end{array}$ & $\begin{array}{l}0.001 \\
(0.03)\end{array}$ & $\begin{array}{l}-0.020 \\
(0.54)\end{array}$ & $\begin{array}{l}-0.016 \\
(0.45)\end{array}$ & $\begin{array}{l}0.003 \\
(0.07)\end{array}$ & $\begin{array}{l}0.008 \\
(0.23)\end{array}$ & $\begin{array}{l}0.001 \\
(0.02)\end{array}$ & $\begin{array}{l}0.006 \\
(0.17)\end{array}$ & $\begin{array}{l}-0.014 \\
(0.39)\end{array}$ & $\begin{array}{l}-0.015 \\
(0.44)\end{array}$ \\
\hline mon_ & $\begin{array}{l}0.748 \\
(2.74)^{* * *}\end{array}$ & $\begin{array}{l}0.736 \\
(2.70)^{* * *}\end{array}$ & $\begin{array}{l}0.737 \\
(2.75)^{* * *}\end{array}$ & $\begin{array}{l}0.722 \\
(2.70)^{* * *}\end{array}$ & $\begin{array}{l}0.943 \\
(2.85)^{* * *}\end{array}$ & $\begin{array}{l}0.921 \\
(2.71)^{* * *}\end{array}$ & $\begin{array}{l}0.750 \\
(2.80)^{* * *}\end{array}$ & $\begin{array}{l}0.745 \\
(2.80)^{* * *}\end{array}$ & $\begin{array}{l}0.731 \\
(2.77)^{* * *}\end{array}$ & $\begin{array}{l}0.727 \\
(2.78)^{* * *}\end{array}$ & $\begin{array}{l}0.934 \\
(2.86)^{* * *}\end{array}$ & $\begin{array}{l}0.936 \\
(2.88)^{* * *}\end{array}$ \\
\hline exrdum_ & $\begin{array}{l}0.009 \\
(2.06)^{* *}\end{array}$ & $\begin{array}{l}0.004 \\
(0.46)\end{array}$ & $\begin{array}{l}0.008 \\
(2.12)^{* *}\end{array}$ & $\begin{array}{l}0.000 \\
(0.03)\end{array}$ & $\begin{array}{l}0.004 \\
(0.85)\end{array}$ & $\begin{array}{l}0.000 \\
(0.01)\end{array}$ & $\begin{array}{l}0.008 \\
(2.16)^{* *}\end{array}$ & $\begin{array}{l}-0.002 \\
(0.16)\end{array}$ & $\begin{array}{l}0.008 \\
(2.24)^{* *}\end{array}$ & $\begin{array}{l}0.000 \\
(0.04)\end{array}$ & $\begin{array}{l}0.004 \\
(0.96)\end{array}$ & $\begin{array}{l}-0.020 \\
(1.85)^{*}\end{array}$ \\
\hline findeap_ & $\begin{array}{l}-0.002 \\
(0.15)\end{array}$ & $\begin{array}{l}-0.001 \\
(0.13)\end{array}$ & $\begin{array}{l}-0.002 \\
(0.24)\end{array}$ & $\begin{array}{l}-0.002 \\
(0.23)\end{array}$ & $\begin{array}{l}0.010 \\
(0.66)\end{array}$ & $\begin{array}{l}0.010 \\
(0.63)\end{array}$ & $\begin{array}{l}0.003 \\
(0.26)\end{array}$ & $\begin{array}{l}0.002 \\
(0.20)\end{array}$ & $\begin{array}{l}0.001 \\
(0.12)\end{array}$ & $\begin{array}{l}0.001 \\
(0.08)\end{array}$ & $\begin{array}{l}0.013 \\
(0.85)\end{array}$ & $\begin{array}{l}0.010 \\
(0.68)\end{array}$ \\
\hline extfin_ & $\begin{array}{l}0.064 \\
(3.50)^{* * * *}\end{array}$ & $\begin{array}{l}0.063 \\
(3.41)^{* * * *}\end{array}$ & $\begin{array}{l}0.061 \\
(3.31)^{* * *}\end{array}$ & $\begin{array}{l}0.060 \\
(3.15)^{* * *}\end{array}$ & $\begin{array}{l}0.088 \\
(6.43)^{* * *}\end{array}$ & $\begin{array}{l}0.088 \\
(6.34)^{* * *}\end{array}$ & $\begin{array}{l}0.069 \\
(3.93)^{* * *}\end{array}$ & $\begin{array}{l}0.067 \\
(3.84)^{* * * *}\end{array}$ & $\begin{array}{l}0.065 \\
(3.64)^{* * * *}\end{array}$ & $\begin{array}{l}0.065 \\
(3.62)^{* * *}\end{array}$ & $\begin{array}{l}0.094 \\
(7.70)^{* * *}\end{array}$ & $\begin{array}{l}0.094 \\
(8.15)^{* * *}\end{array}$ \\
\hline rppppc & $\begin{array}{l}0.000 \\
(1.07)\end{array}$ & $\begin{array}{l}0.000 \\
(1.08)\end{array}$ & $\begin{array}{l}0.000 \\
(0.96)\end{array}$ & $\begin{array}{l}0.000 \\
(0.93)\end{array}$ & $\begin{array}{l}0.000 \\
(1.62)\end{array}$ & $\begin{array}{l}0.000 \\
(1.62)\end{array}$ & $\begin{array}{l}0.000 \\
(1.43)\end{array}$ & $\begin{array}{l}0.000 \\
(1.36)\end{array}$ & $\begin{array}{l}0.000 \\
(1.25)\end{array}$ & $\begin{array}{l}0.000 \\
(1.23)\end{array}$ & $\begin{array}{l}0.000 \\
(2.00)^{* *}\end{array}$ & $\begin{array}{l}0.000 \\
(2.03)^{* *}\end{array}$ \\
\hline rpppwgt_ & $\begin{array}{l}0.001 \\
(2.78)^{* * * *}\end{array}$ & $\begin{array}{l}0.001 \\
(2.75)^{* * *}\end{array}$ & $\begin{array}{l}0.001 \\
(2.91)^{* * *}\end{array}$ & $\begin{array}{l}0.001 \\
(2.88)^{* * *}\end{array}$ & $\begin{array}{l}0.002 \\
(1.89)^{*}\end{array}$ & $\begin{array}{l}0.002 \\
(1.87)^{*}\end{array}$ & $\begin{array}{l}0.001 \\
(2.67)^{* * *}\end{array}$ & $\begin{array}{l}0.001 \\
(2.68)^{* * *}\end{array}$ & $\begin{array}{l}0.001 \\
(2.83)^{* * * *}\end{array}$ & $\begin{array}{l}0.001 \\
(2.83)^{* * *}\end{array}$ & $\begin{array}{l}0.002 \\
(1.60)\end{array}$ & $\begin{array}{l}0.002 \\
(1.65)^{*}\end{array}$ \\
\hline interv_ & & & $\begin{array}{l}0.052 \\
(1.50)\end{array}$ & $\begin{array}{l}0.054 \\
(1.45)\end{array}$ & & & & & $\begin{array}{l}0.050 \\
(1.45)\end{array}$ & $\begin{array}{l}0.037 \\
(1.20)\end{array}$ & & \\
\hline Constant & $\begin{array}{l}-0.009 \\
(0.63)\end{array}$ & $\begin{array}{l}-0.008 \\
(0.50)\end{array}$ & $\begin{array}{l}-0.009 \\
(0.64)\end{array}$ & $\begin{array}{l}-0.006 \\
(0.41)\end{array}$ & $\begin{array}{l}-0.032 \\
(1.59)\end{array}$ & $\begin{array}{l}-0.030 \\
(1.36)\end{array}$ & $\begin{array}{l}-0.042 \\
(2.17)^{* *}\end{array}$ & $\begin{array}{l}-0.035 \\
(1.74)^{*}\end{array}$ & $\begin{array}{l}-0.039 \\
(1.93)^{*}\end{array}$ & $\begin{array}{l}-0.033 \\
(1.59)\end{array}$ & $\begin{array}{l}-0.069 \\
(3.19)^{* * *}\end{array}$ & $\begin{array}{l}-0.046 \\
(1.93)^{*}\end{array}$ \\
\hline Observations & 252 & 252 & 251 & 251 & 171 & 171 & 252 & 252 & 251 & 251 & 171 & 171 \\
\hline
\end{tabular}

Note: Robust $\mathrm{z}$ statistics in parentheses. REER, real effective exchange rate.

* Significant at 10\%; ** significant at 5\%; *** significant at $1 \%$. 
Table 9. Volatility of Growth in REER, Basic Table: 1986-2002 (22 Emerging Market Economies)

\begin{tabular}{|c|c|c|c|c|c|c|c|c|}
\hline & Main & Main & Only sig. & Only sig. & No outliers & No outliers & W/ interv & $\mathrm{W} /$ interv \\
\hline \multirow[t]{2}{*}{ logresstd_L } & -0.001 & 0.000 & -0.005 & -0.001 & -0.000 & -0.000 & -0.001 & 0.000 \\
\hline & $(0.97)$ & $(0.14)$ & $(2.85)^{* * *}$ & $(0.47)$ & $(0.36)$ & $(0.27)$ & $(0.86)$ & $(0.23)$ \\
\hline \multirow[t]{2}{*}{ logresstd_LD } & & -0.004 & & -0.008 & & -0.000 & & -0.004 \\
\hline & & $(0.97)$ & & $(1.81)^{*}$ & & $(0.05)$ & & (0.93) \\
\hline \multirow[t]{2}{*}{ gro_ } & -0.180 & -0.177 & -0.208 & -0.191 & -0.127 & -0.127 & -0.181 & -0.179 \\
\hline & $(3.58)^{* * *}$ & $(3.64) * * *$ & $(3.70)^{* * *}$ & $(3.79) * * *$ & $(2.86) * * *$ & $(2.91)^{* * *}$ & $(3.65) * * *$ & $(3.70)^{* * *}$ \\
\hline \multirow[t]{2}{*}{ fis_ } & 0.052 & 0.048 & 0.074 & 0.051 & 0.014 & 0.015 & 0.052 & 0.047 \\
\hline & (1.44) & (1.25) & $(2.21)^{* *}$ & (1.36) & $(0.30)$ & $(0.31)$ & (1.46) & (1.27) \\
\hline \multirow[t]{2}{*}{ infl_ } & 0.004 & 0.004 & & & 0.018 & 0.018 & 0.005 & 0.004 \\
\hline & $(0.66)$ & $(0.59)$ & & & $(2.18)^{* *}$ & $(2.04)^{* *}$ & $(0.66)$ & $(0.58)$ \\
\hline \multirow[t]{2}{*}{ tot_ } & 0.017 & 0.015 & & & -0.014 & -0.015 & 0.015 & 0.013 \\
\hline & $(0.57)$ & $(0.49)$ & & & $(0.44)$ & $(0.47)$ & $(0.51)$ & $(0.42)$ \\
\hline \multirow[t]{2}{*}{ tropen_ } & -0.006 & -0.006 & & & -0.010 & -0.010 & -0.005 & -0.006 \\
\hline & (0.59) & $(0.63)$ & & & (1.35) & (1.34) & $(0.54)$ & $(0.58)$ \\
\hline \multirow[t]{2}{*}{ mon_ } & 0.512 & 0.516 & 0.538 & 0.552 & 0.501 & 0.502 & 0.514 & 0.518 \\
\hline & $(3.02)^{* * *}$ & $(3.04)^{* * *}$ & $(3.69) * * *$ & $(4.12)^{* * *}$ & $(2.69) * * *$ & $(2.67) * * *$ & $(3.01)^{* * *}$ & $(3.03)^{* * *}$ \\
\hline \multirow[t]{2}{*}{ exrdum_ } & 0.018 & 0.016 & & & 0.012 & 0.012 & 0.018 & 0.016 \\
\hline & $(4.62)^{* * *}$ & $(3.95)^{* * *}$ & & & $(3.95) * * *$ & $(3.53) * * *$ & $(4.52) * * *$ & $(3.93) * * *$ \\
\hline \multirow[t]{2}{*}{ findeap_ } & 0.004 & 0.002 & & & 0.012 & 0.012 & 0.003 & 0.002 \\
\hline & $(0.43)$ & $(0.26)$ & & & $(1.82)^{*}$ & $(1.88)^{*}$ & $(0.38)$ & $(0.25)$ \\
\hline \multirow[t]{2}{*}{ extfin_ } & 0.027 & 0.028 & 0.028 & 0.027 & 0.012 & 0.012 & 0.027 & 0.028 \\
\hline & $(2.02)^{* *}$ & $(2.01)^{* *}$ & $(2.03)^{* *}$ & $(1.89)^{*}$ & $(0.95)$ & $(0.90)$ & $(2.10)^{* *}$ & $(2.14)^{* *}$ \\
\hline \multirow[t]{2}{*}{ rррррс } & -0.000 & -0.000 & & & -0.000 & -0.000 & -0.000 & -0.000 \\
\hline & $(0.57)$ & $(0.60)$ & & & $(0.25)$ & $(0.28)$ & $(0.58)$ & $(0.58)$ \\
\hline \multirow[t]{2}{*}{ rpppwgt_ } & 0.001 & 0.001 & 0.001 & 0.001 & 0.000 & 0.000 & 0.001 & 0.001 \\
\hline & $(1.90)^{*}$ & $(1.83)^{*}$ & $(3.40)^{* * *}$ & $(3.03)^{* * *}$ & $(0.78)$ & $(0.75)$ & $(1.91)^{*}$ & $(1.83)^{*}$ \\
\hline \multirow[t]{2}{*}{ interv_ } & & & & & & & -0.004 & -0.009 \\
\hline & & & & & & & $(0.22)$ & $(0.50)$ \\
\hline \multirow[t]{2}{*}{ Constant } & 0.003 & 0.004 & 0.007 & 0.005 & 0.006 & 0.006 & 0.003 & 0.004 \\
\hline & $(0.25)$ & $(0.35)$ & $(0.90)$ & $(0.64)$ & $(0.64)$ & $(0.70)$ & $(0.27)$ & $(0.34)$ \\
\hline Observations & 374 & 374 & 374 & 374 & 323 & 323 & 371 & 371 \\
\hline No. of countries & 22 & 22 & 22 & 22 & 19 & 19 & 22 & 22 \\
\hline
\end{tabular}

Note: Robust z statistics in parentheses. REER, real effective exchange rate.

* Significant at 10\%; ** significant at 5\%; *** significant at $1 \%$. 
Table 10. Identification Through Heteroscedasticity (IH): 1994-2002 (The effect of reserve to short-term debt ratio on REER volatility)

\begin{tabular}{lccc}
\hline & Main $^{1 /}$ & Signif. controls $^{2 /}$ & With intervention proxy $^{3 /}$ \\
\hline invexpRS & $0.025^{* * *}$ & $0.033^{* * *}$ & $0.025 * * *$ \\
\hline
\end{tabular}

Note: *** Corresponds to significance at 1 percent. REER, real effective exchange rate. 1/ "Main" regression includes all control variables (apart from exchange rate dummy).

2/ "Signif. control" regression excludes usual insignificant control variable (and exchange rate dummy).

3/ "With intervention proxy" includes the "interv_" variable. 
Table 11. Volatility of Growth in REER, OLS and Fixed Effects: 1994-2002 (28 Emerging Market Economies)

\begin{tabular}{|c|c|c|c|c|c|c|c|c|}
\hline & OLS & FE & OLS & FE & OLS & FE & OLS & FE \\
\hline invexpRS & $\begin{array}{l}0.042 \\
(5.01)^{* * *}\end{array}$ & $\begin{array}{l}0.069 \\
(3.89)^{* * *}\end{array}$ & & & $\begin{array}{l}0.015 \\
(2.47)^{* *}\end{array}$ & $\begin{array}{l}0.030 \\
(1.99)^{* *}\end{array}$ & & \\
\hline logresstd_L & & & $\begin{array}{l}-0.010 \\
(4.84)^{* * *}\end{array}$ & $\begin{array}{l}-0.016 \\
(3.49)^{* * *}\end{array}$ & & & $\begin{array}{l}-0.004 \\
(2.27)^{* *}\end{array}$ & $\begin{array}{l}-0.007 \\
(1.77)^{*}\end{array}$ \\
\hline $\mathrm{gro}_{-}$ & & & & & $\begin{array}{l}-0.224 \\
(5.30)^{* * *}\end{array}$ & $\begin{array}{l}-0.193 \\
(4.52)^{* * *}\end{array}$ & $\begin{array}{l}-0.222 \\
(5.26)^{* * *}\end{array}$ & $\begin{array}{l}-0.192 \\
(4.46)^{* * *}\end{array}$ \\
\hline fis & & & & & $\begin{array}{l}0.101 \\
(1.68)^{*}\end{array}$ & $\begin{array}{l}0.031 \\
(0.43)\end{array}$ & $\begin{array}{l}0.099 \\
(1.67)^{*}\end{array}$ & $\begin{array}{l}0.032 \\
(0.45)\end{array}$ \\
\hline infl_ & & & & & $\begin{array}{l}-0.010 \\
(1.22)\end{array}$ & $\begin{array}{l}-0.017 \\
(1.46)\end{array}$ & $\begin{array}{l}-0.010 \\
(1.25)\end{array}$ & $\begin{array}{l}-0.017 \\
(1.51)\end{array}$ \\
\hline tot_ & & & & & $\begin{array}{l}0.007 \\
(0.20)\end{array}$ & $\begin{array}{l}-0.009 \\
(0.22)\end{array}$ & $\begin{array}{l}0.006 \\
(0.16)\end{array}$ & $\begin{array}{l}-0.011 \\
(0.25)\end{array}$ \\
\hline tropen_ & & & & & $\begin{array}{l}-0.007 \\
(1.42)\end{array}$ & $\begin{array}{l}0.004 \\
(0.28)\end{array}$ & $\begin{array}{l}-0.007 \\
(1.45)\end{array}$ & $\begin{array}{l}0.004 \\
(0.35)\end{array}$ \\
\hline $\mathrm{mon}_{-}$ & & & & & $\begin{array}{l}0.581 \\
(3.89)^{* * *}\end{array}$ & $\begin{array}{l}0.759 \\
(3.32)^{* * *}\end{array}$ & $\begin{array}{l}0.585 \\
(3.91)^{* * *}\end{array}$ & $\begin{array}{l}0.765 \\
(3.34)^{* * *}\end{array}$ \\
\hline exrdum_ & & & & & $\begin{array}{l}0.010 \\
(3.05)^{* * *}\end{array}$ & $\begin{array}{l}0.005 \\
(0.98)\end{array}$ & $\begin{array}{l}0.010 \\
(3.05)^{* * *}\end{array}$ & $\begin{array}{l}0.004 \\
(0.93)\end{array}$ \\
\hline findeap_ & & & & & $\begin{array}{l}-0.004 \\
(0.54)\end{array}$ & $\begin{array}{l}-0.015 \\
(0.56)\end{array}$ & $\begin{array}{l}-0.004 \\
(0.65)\end{array}$ & $\begin{array}{l}-0.018 \\
(0.64)\end{array}$ \\
\hline extfin_ & & & & & $\begin{array}{l}0.058 \\
(4.47)^{* * *}\end{array}$ & $\begin{array}{l}0.091 \\
(5.91)^{* * *}\end{array}$ & $\begin{array}{l}0.059 \\
(4.55)^{* * *}\end{array}$ & $\begin{array}{l}0.093 \\
(6.22)^{* * *}\end{array}$ \\
\hline rррррс $c_{-}$ & & & & & $\begin{array}{l}0.000 \\
(0.71)\end{array}$ & $\begin{array}{l}-0.000 \\
(0.22)\end{array}$ & $\begin{array}{l}0.000 \\
(0.69)\end{array}$ & $\begin{array}{l}-0.000 \\
(0.45)\end{array}$ \\
\hline rpppwgt_ & & & & & $\begin{array}{l}0.001 \\
(4.12)^{* * *}\end{array}$ & $\begin{array}{l}0.000 \\
(0.10)\end{array}$ & $\begin{array}{l}0.001 \\
(4.19)^{* * *}\end{array}$ & $\begin{array}{l}0.000 \\
(0.47)\end{array}$ \\
\hline Constant & $\begin{array}{l}0.012 \\
(5.30)^{* * *}\end{array}$ & $\begin{array}{l}0.000 \\
(0.03)\end{array}$ & $\begin{array}{l}0.028 \\
(14.49)^{* * *}\end{array}$ & $\begin{array}{l}0.030 \\
(1.63)\end{array}$ & $\begin{array}{l}-0.013 \\
(1.26)\end{array}$ & $\begin{array}{l}-0.033 \\
(1.16)\end{array}$ & $\begin{array}{l}-0.007 \\
(0.74)\end{array}$ & $\begin{array}{l}-0.016 \\
(0.63)\end{array}$ \\
\hline Observations & 252 & 252 & 252 & 252 & 252 & 252 & 252 & 252 \\
\hline$R$-squared & 0.12 & 0.32 & 0.10 & 0.31 & 0.55 & 0.68 & 0.55 & 0.67 \\
\hline
\end{tabular}

Note: Absolute value of $t$-statistics in parentheses. REER, real effective exchange rate;

OLS, ordinary least squares; FE, fixed-effects.

* Significant at $10 \%$; ${ }^{* *}$ significant at $5 \%$; *** significant at $1 \%$. 
Figure 2: Outliers Versus Leverage Residuals: 1994-2002

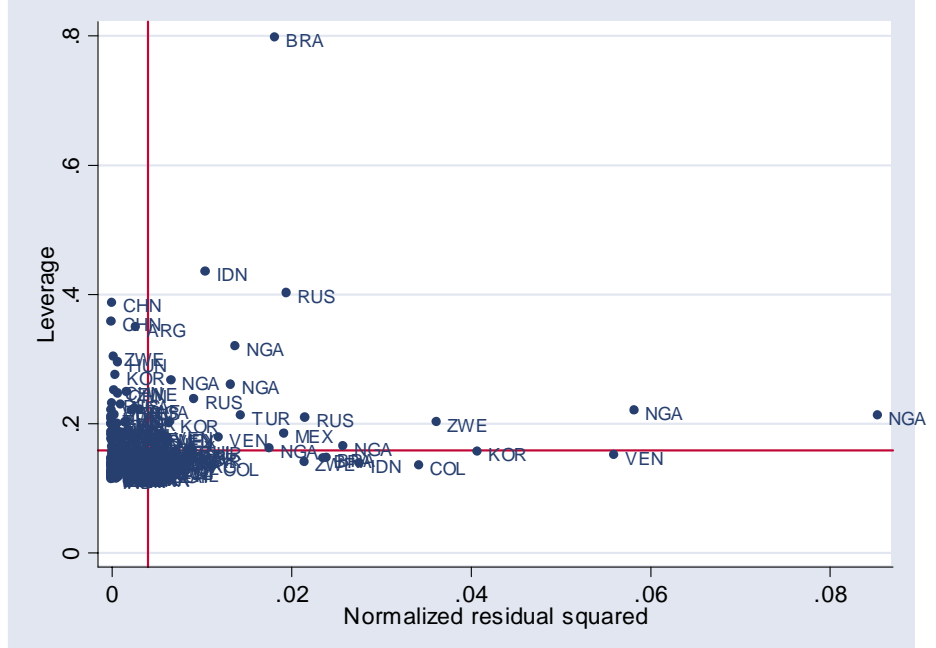

Figure 3: Outliers Versus Leverage Residuals: 1986-2002

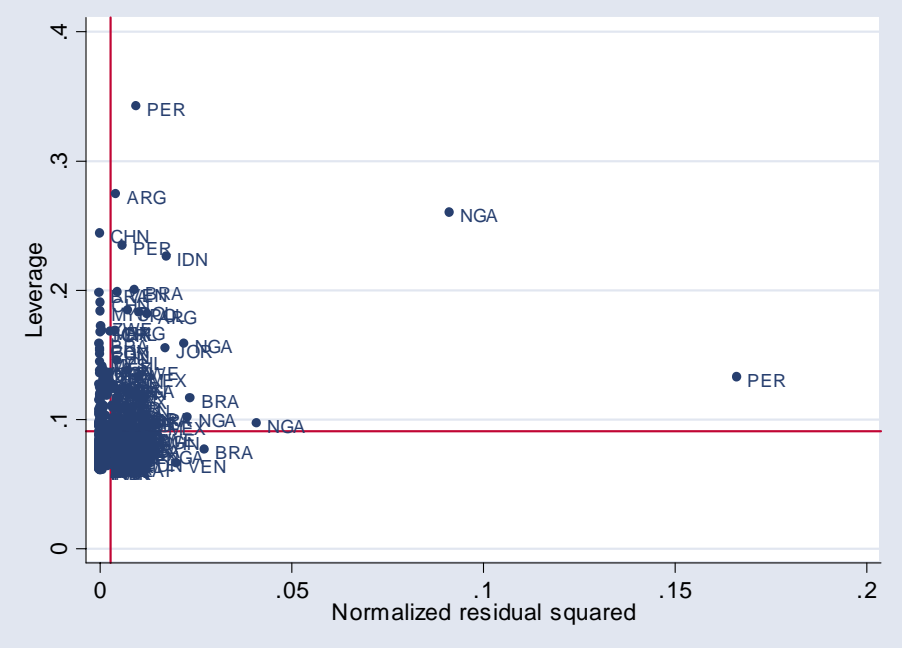




\section{REFERENCES}

Bartolini, Leonardo, and Gordon M. Bodnar, 1996, “Are Exchange Rates Excessively Volatile? And What Does ‘Excessive Volatile’ Mean, Anyway?” IMF Staff Papers, Vol. 43, pp. 72-96.

Calvo, Guillermo, and Carmen M. Reinhart, 1999, "When Capital Inflows Come to a Sudden Stop: Consequences and Policy Options,” in P. Kenen and A. Swoboda, Key Issues in Reform of the International Monetary and Financial System, (Washington: International Monetary Fund).

Canales-Kriljenko, Jorge and Karl Habermeier, 1999, "Factors Affecting Exchange Rate Volatility," in Exchange Arrangements and Foreign Exchange Markets;

Developments and Issues, World Economic and Financial Surveys, International Monetary Fund.

Caramazza, F., L. A. Ricci, and R. Salgado, 2004, "International Financial Contagion in Currency Crises", Journal of International Money and Finance, Vol. 23, pp. 51-70.

Christofides, C., C. Mulder, and A. Tiffin, 2003, “The Link Between Adherence to International Standards of Good Practice, Foreign Exchange Spreads, and Ratings,” IMF Working Paper 03/74 (Washington: International Monetary Fund).

Clark, P., A. Sadikov, N. Tamirisia, S-J. Wei, and L. Zeng, 2003, "Exchange Rate Volatility and Trade Flows", forthcoming, International Monetary Fund.

Devereux, Michael B., and Charles Engel, 2002, "Exchange Rate Pass-Through, Exchange Rate Volatility, and Exchange Rate Disconnect,” Journal of Monetary Economics (July), pp. 913-40.

Devereux, Michael B. and Philip R. Lane, 2003, “Understanding Bilateral Exchange Rate Volatility,” Journal of International Economics, Vol. 50 , pp. 109-132.

Dornbusch, Rudiger, 1976, “Expectations and Exchange Rate Dynamics,” Journal of Political Economy, Vol. 84, No. 6, pp. 1161-76.

Hasan, Shahriar and Myles Wallace, 1996, "Real Exchange Rate Volatility and Exchange Rate Regimes: Evidence from Long-Term Data,” Economic Letters, Vol. 52 (July), pp. 67-73.

Hausmann, Ricardo, Ugo Panizza, and Ernesto Stein, 2001, "Why do Countries Float the Way They Float?” Journal of Development Economics, Vol. 66, pp. 387-414. 
International Monetary Fund, 1998 (and other years), World Economic Outlook (Washington, October and May).

Jonsson, Gunnar, 2001, “The Risk Premium in South African Long-term Interest Rates,” South Africa-Recent Economic Developments, IMF, SM/01/79.

Lee, Jaewoo, 2004, "Insurance Value of International Reserves: An Option-pricing Approach,” forthcoming, International Monetary Fund.

Levy-Yeyati, Eduardo, and Federico Sturzeneger, 2002, “Classifying Exchange Rate Regimes: Deeds vs. Words,” forthcoming, European Economic Review.

Mulder, Christian, Roberto Perrelli, and Manuel Rocha, 2002, “The Role of Corporate, Legal and Macroeconomic Balance Sheet Indicators in Crisis Detection and Prevention,” IMF Working Paper 02/59 (Washington: International Monetary Fund).

Reinhart, Carmen M. and Kenneth S. Rogoff, 2002, "the Modern History of Exchange Rate Arrangments: A Reinterpretation,” NBER Working Paper No. 8963 (Cambridge: National Bureau of Economic Research).

Rigobon, Roberto, 2003, “Identification through Heteroskedasticity,” Review of Economic Statistics, Vol. 85, No. 4, pp. 777-792.

Rose, Andrew K., 1994, “Are Exchange Rates Macroeconomic Phenomena?” Federal Reserve Bank of San Francisco Economic Review, pp. 19-30. 